\title{
Therapeutic strategies targeting Wnt/ $\beta$-catenin signaling for colorectal cancer (Review)
}

\author{
YONG JI ${ }^{1}$, JIAN LV ${ }^{1}$, DI SUN ${ }^{1}$ and YUFENG HUANG ${ }^{2}$ \\ Departments of ${ }^{1}$ General Surgery and ${ }^{2}$ Oncology, Jingjiang People's Hospital, Jingjiang, Jiangsu 214500, P.R. China
}

Received July 16, 2021; Accepted October 20, 2021

DOI: 10.3892/ijmm.2021.5056

\begin{abstract}
Colorectal cancer (CRC) is one of the most common carcinomas. Although great progress has been made in recent years, CRC survival remains unsatisfactory due to high metastasis and recurrence. Understanding the underlying molecular mechanisms of CRC tumorigenesis and metastasis has become increasingly important. Recently, aberrant Wnt/ $\beta$-catenin signaling has been reported to be strongly associated with CRC tumorigenesis, metastasis and recurrence. Therefore, the $\mathrm{Wnt} / \beta$-catenin signaling pathway has potential value as a therapeutic target for CRC. In the present review, the dysregulation of this pathway in $\mathrm{CRC}$ and the promoting or suppressing function of therapeutic targets on CRC were explored. In addition, the interaction between this pathway and epithelial-mesenchymal transition (EMT), cell stemness, mutations, metastasis-related genes and tumor angiogenesis in CRC cells were also investigated. Numerous studies on this pathway may help identify the potential diagnostic and prognostic markers and therapeutic targets for CRC.
\end{abstract}

\section{Contents}

1. Introduction

2. Role of $\mathrm{Wnt} / \beta$-catenin signaling in colorectal cancer (CRC)

3 . Therapeutic strategies targeting Wnt/ $\beta$-catenin signaling for CRC

4. Challenges in targeting $\mathrm{Wnt} / \beta$-catenin signaling in CRC

5. Conclusions and future perspectives

\section{Introduction}

CRC is considered to be a highly metastatic disease that occurs in the colon, rectum and appendix (1). Globally, CRC

Correspondence to: Dr Yufeng Huang, Department of Oncology, Jingjiang People's Hospital, 28 Zhongzhou Road, Jingjiang, Jiangsu 214500, P.R. China

E-mail: wangyutingwangxin@163.com

Key words: therapeutic strategy, Wnt, $\beta$-catenin, colorectal cancer is one of the most common carcinomas and has remained as the second leading cause of carcinoma-associated mortality since 2008 (2). Generally, patients with CRC in stages 1 and 2 have a relatively favorable prognosis and 5-year survival rate, whereas the prognosis of those in stage 4 is very poor (3). Only $39 \%$ of patients with CRC are diagnosed in the early stages (4). Increased data have shown that the 5-year survival rate of patients with metastatic CRC is $10-15 \%$, indicating a poor prognosis (5). Additionally, invasion and metastasis contribute to $90 \%$ of CRC-related mortalities (6). For advanced or metastatic CRC, surgical removal alone fails to be curative. Accordingly, understanding the underlying molecular mechanisms of CRC progression and metastasis has become increasingly important. It has been demonstrated that the $\mathrm{Wnt} / \beta$-catenin signaling pathway is implicated in the proliferation, invasion and metastasis of CRC cells $(7,8)$. The Wnt signaling pathway is divided into two main categories, the non-canonical ( $\beta$-catenin-independent) and canonical ( $\beta$-catenin-dependent) pathways $(9,10)$. Wnt ligands are an evolutionary conserved family of 19 secreted glycoproteins produced in the endoplasmic reticulum (ER) of mammalians (11). $\beta$-catenin is one of the Armadillo repeat protein superfamily and a primary transducer of Wnt signals (12). In the present review, the potential underlying mechanism of the canonical Wnt pathway in CRC and possible therapeutic strategies were explored to further understand the mode of action of this canonical pathway on CRC.

In the absence of Wnt ligands, cytoplasmic $\beta$-catenin is targeted for proteasome-mediated degradation via the association with a destruction complex (13), mainly including adenomatous polyposis coli (APC), axis inhibition protein 1 (Axin1), glycogen synthase kinase-3 $\beta$ (GSK-3 $\beta$ ), casein kinase 1 (CK1) and E3-ubiquitinligase $\beta$-transducin repeats-containing protein $(\beta-\operatorname{TrCP})(14)$. In the presence of Wnt ligands, the biding of Wnt ligands to their cognate receptors [frizzled (FZD)/low-density lipoprotein receptor-related protein 5 or 6 receptor (LRP5/6)] triggers the recruitment of Axin1 to the Axin-binding molecule Dishevelled (DVL), leading to the disassembly of the destruction complex $(14,15)$. Following the disassembly, the stabled $\beta$-catenin accumulates in the cytoplasm, and subsequently translocates into the nucleus where it binds to TCF/LEF, together with the recruitment of co-activator complexes to activate the downstream target genes of Wnt/ $\beta$-catenin signaling (16). These downstream genes mainly include cyclin D1, c-Myc, matrix metalloproteinase 
(MMP)-7, leucine-rich repeat-containing $\mathrm{G}$ protein-coupled receptor 5 (Lgr5), CD44, Axin2 (17,18) and surviving (19). A schematic diagram depicting the molecular mechanism of the members of the $\mathrm{Wnt} / \beta$-catenin signaling pathway involved in inducing the expression of its downstream target genes is presented in Fig. 1. To develop effective targeted therapies, it is necessary to understand the molecular mechanisms of Wnt/ $\beta$-catenin-mediated CRC proliferation, invasion and metastasis. This review focused on the relationship between the $\mathrm{Wnt} / \beta$-catenin signaling pathway and the promising therapeutic targets for CRC. The present review included 178 references. Databases including 'Pubmed', 'SpringerLink' and 'Clinical key' were used to search for the cited studies. The key words searched included 'Wnt/ $\beta$-catenin', 'colorectal cancer', 'CRC', 'therapy', and 'treatment'.

\section{Role of Wnt/ $\beta$-catenin signaling in colorectal cancer (CRC)}

A previous study has demonstrated that activation of the Wnt/ $\beta$-catenin signaling pathway and overexpression of its downstream genes, such as c-Myc and cyclin D1, promote CRC tumorigenesis (8). Additionally, several mechanisms by which the $\mathrm{Wnt} / \beta$-catenin signaling pathway is aberrantly activated are presented below.

Aberrant accumulation of $\beta$-catenin. Loss of APC contributes to the aberrant accumulation of nuclear $\beta$-catenin, which is a hallmark of CRC progression and activation of Wnt/ $\beta$-catenin signaling (20). $\beta$-catenin knockdown effectively promotes the apoptosis of CRC cells (21). The cooperation of nuclear $\beta$-catenin with TCF/LEF induces the transcription of c-MYC oncogene, which is upregulated in CRC (22). Increased cyclin D1 transcription as a result of high levels of $\beta$-catenin occurs in colon cancer cells (23). Furthermore, c-Myc and cyclin D1 together with APC gene mutations contribute to autonomous proliferation of colon cancer cells (24). Therefore, aberrant activation of $\mathrm{Wnt} / \beta$-catenin signaling due to the accumulation of $\beta$-catenin may contribute to the initiation and progression of CRC via the upregulation of cyclin D1 and c-Myc (25). Additionally, high levels of nuclear $\beta$-catenin expression occur at the invasion front of CRC, and they are associated with poor prognosis (26). These findings indicate that the aberrant accumulation of nuclear $\beta$-catenin and the failure of $\beta$-catenin degradation contribute to CRC development.

Mutations. Investigation of the underlying mechanism of how Wnt/ $\beta$-catenin-related mutations affect CRC has demonstrated that mutations aberrantly activate this pathway leading to the onset of $\mathrm{CRC}$ tumorigenesis. It is reported that mutations in the $\mathrm{Wnt} / \beta$-catenin signaling pathway contribute to initiating the majority of CRC $(27,28)$ and $90 \%$ of sporadic patients with CRC harbor mutations in the core components of the Wnt/ $\beta$-catenin pathway (29). The development and progression of CRC due to mutations in this pathway involve a cascade of genetic events. A previous study suggested significantly aberrant methylation in mutated genes, including Wnt2, Wnt3A, Wnt6, FZD5, LRP5 and TCF7L1 in sporadic CRC (30). Wnt ligands, such as Wnt4, are reported to be upregulated in the serum of patients with CRC and CRC tissues (31). Extensive evidence indicates that mutations in APC, $\beta$-catenin, Axin1, Axin2 and TCF-4 initiate the process of $\mathrm{CRC}$ tumorigenesis (32-38). These mutations are identified in the earliest neoplasms showing that this pathway plays a vital role in colorectal tumorigenesis (39). Although a study has suggested that mutations in multiple components of this pathway occur in the hyper-mutated neoplasms, most neoplasms harbor a mutation in a single component of the Wnt/ $\beta$-catenin pathway $(14,40)$.

CRC cell stemness and epithelial-mesenchymal transition $(E M T)$. Cancer stem-like cells (CSCs) and EMT are major factors contributing to the metastasis of cancer cells $(6,41)$. Patients with CRC develop recurrence and metastasis owing to the survival of CSCs. Numerous studies have provided evidence for the role of EMT in the acquisition of the CSC phenotype in CRC and have suggested that EMT may facilitate CSC formation $(42,43)$. It is currently not understood how EMT enables CSCs to reside in the CRC microenvironment to escape the effects of chemotherapy. Recently, accumulating evidence has shown the pivotal role of $\mathrm{Wnt} / \beta$-catenin signaling in CRC stem-like cells and EMT $(41,44-46)$.

In $\mathrm{CRC}$, aberrant activation of $\mathrm{Wnt} / \beta$-catenin signaling disrupts the $\mathrm{Wnt} / \beta$-catenin gradient, leading to the hyperplasia of intestinal stem cells along the crypt-villus axis and contributing to tumor initiation via CRC stem-like cells (47). To clarify the underlying molecular mechanisms of CRC stem-like cells in Wnt/ $\beta$-catenin signaling, an increasing number of studies have focused on identifying the markers of CRC stem cells. For example, Lgr5 has been identified as a surface marker of CRC stem cells, and its high expression is involved in the development and progression of CRC (21). In 2007, CD133 was first identified as a potential specific marker of colon CSCs, although the role of CD133 has been questioned (42). A recent meta-analysis study suggested that CD133 is strongly associated with poor prognosis and vascular invasion in CRC (48). Additionally, great progress has been achieved in identifying other CRC stem-like cell markers, such as aldehydedehydrogenase-1, homeobox protein NANOG, achaete-scute family bhlh transcription factor 2, SRY-Box 2 and octamer-binding protein 3/4, as well as CRC stem-like cell surface markers, such as CD24, CD29, CD44 and CD166 $(45,49,50)$.

$\mathrm{Wnt} / \beta$-catenin signaling plays a critical role in EMT via inducing the expression of EMT-associated nuclear factor- $\kappa \mathrm{B}(51)$. Wnt $/ \beta$-catenin signaling may promote EMT, in which $\beta$-catenin and GSK-3 $\beta$ are two key players (46). Ectopic expression of $\beta$-catenin, which is strongly associated with EMT in CRC cells, contributes to the dedifferentiation of post-mitotic intestinal epithelial cells, resulting in the generation of tumor-initiating cells (52). In the $\mathrm{Wnt} / \beta$-catenin signaling pathway, the E-cadherin/ $\beta$-catenin complex usually exists at the membrane, contributing to tight cell-cell interactions and inhibition of cell mobility (53). The disturbance of this complex may promote the nuclear translocation of $\beta$-catenin and induce the transcription of EMT-promoting genes (54). EMT markers mainly contain the epithelial markers [E-cadherin and tight junction protein ZO-1 (ZO-1)] and the mesenchymal markers [N-cadherin, vimentin, Snail, MMP-9, Smad2, fibronectin and Zinc finger E-box binding homeobox 1 (ZEB1)] (1,6,55-57). TCF-4, cyclinD1, c-Myc, Twist-related protein 1 (Twist) and 
A

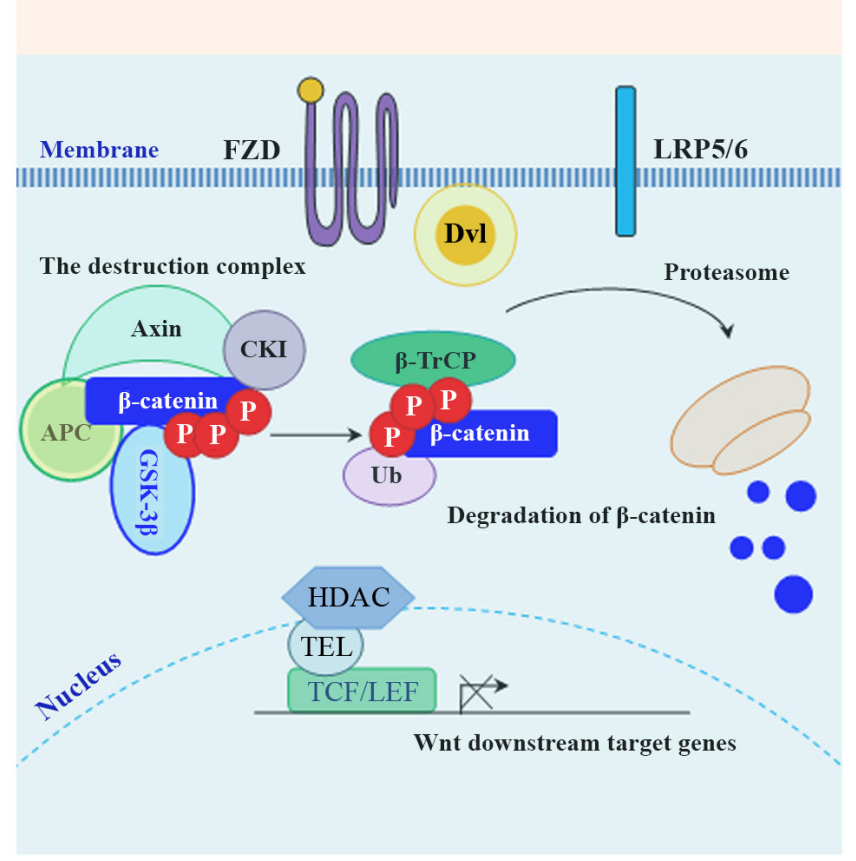

B

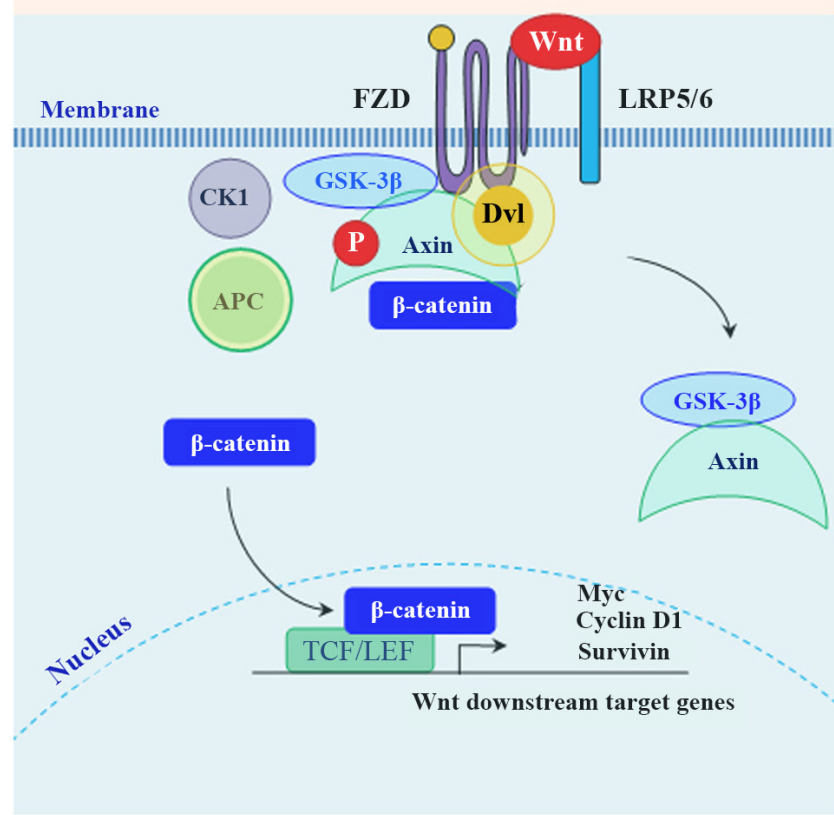

Figure 1. Schematic illustration of the Wnt/ $\beta$-catenin signaling pathway. (A) Inactive Wnt/ $\beta$-catenin pathway: In the absence of Wnt ligands, GSK-3 $\beta$ and CK1 phosphorylate $\beta$-catenin for poly-ubiquitination by $\beta$-TrCP and subsequent proteasome-mediated degradation. (B) Active $\beta$-catenin pathway: In the presence of Wnt ligands, the formation of the destruction complex is affected, leading to the nuclear translocation of $\beta$-catenin. GSK-3 $\beta$, glycogen synthase kinase-3 $\beta$; CK1, casein kinase $1 ; \beta$-TrCP, $\beta$-transducin repeats-containing protein.

MMP-14 are active factors in the EMT process (58). Snail, a direct target of the $\beta$-catenin/TCF complex and also an EMT-initiating gene, is upregulated in the process of EMT (59) and is known to activate EMT during cancer metastasis (12). Recently, certain results suggested that $\beta$-catenin-mediated expression of MMPs also induces EMT and increases the migratory and invasive capabilities of CRC cells via MMP-mediated degradation of the extracellular matrix $(1,60)$.

Abnormality of non-coding RNAs (ncRNAs). NcRNAs constitute more than $90 \%$ of RNAs from the human genome, and according to their size ncRNAs can be divided into different classes including small ncRNAs [such as microRNA (miRNA), piRNAs and tsRNAs], long non-coding RNAs (lncRNAs) and subclasses of IncRNAs (such as circRNAs and pseudogenes) (61). Aberrantly expressed ncRNAs have been demonstrated to be associated with CRC tumorigenesis (25,62-67). Additionally, the aberrant expression of ncRNAs is correlated to the clinicopathological characteristics of CRC, such as prognosis (68), survival $(69,70)$ and metastasis $(1,7,8,62,71-75)$. In the present review, the aberrant expression of ncRNAs and their effects on $\mathrm{CRC}$ in the $\mathrm{Wnt} / \beta$-catenin signaling pathway are presented in Table I (5,7,8,25,36,62-70,72-94).

miRNAs, with a length of 20-24 nucleotides, have been demonstrated to be post-transcriptional regulators in tumorigenesis $(5,7)$. Among the dysregulated miRNAs, some are upregulated $(69,70)$, however others are downregulated $(76,80)$ in CRC cell lines or tissues. miRNAs are the most extensively studied in cancers compared with other small ncRNA species, such as piRNAs and tsRNAs (61). As revealed in Table I, certain miRNAs as oncogenes, promote CRC tumorigenesis and drug resistance combined with other regulators or pathways, including: i) Negatively regulating DKK1 by binding to Wnt-receptor complexes (LRP5 and LRP6) (5); ii) upregulating $\beta$-catenin $(5,78)$ and phosphorylated GSK-3 $\beta(5,78)$, and downregulating GSK-3 $\beta(69,78)$ and phosphorylated- $\beta$-catenin $(78)$; iii) promoting the expression of $\mathrm{Wnt} / \beta$-catenin signaling responsive target genes, such as Lgr5 (70), CD44 (70) and Axin2 (70); iv) upregulating ABCG2 through Wnt/ $\beta$-catenin signaling (ABCG2 is a major multidrug resistance pump that enables cancer cells to resist chemotherapeutic drugs. Wnt/ $\beta$-catenin signaling is one of the upstream mechanisms to regulate the expression of ABCG2 in CRC stem-like cells. The upregulation of miRNA-199a/b contributes to the drug resistance of CRC stem-like cells via upregulating ABCG2 due to the downregulation of GSK-3 $\beta$ and the upregulation of $\beta$-catenin.) (69); v) inhibiting the HBP1-mediated inactivation of Wnt/ $\beta$-catenin signaling (70); vi) inducing EMT via the upregulation of vimentin (78) and N-cadherin (78), and downregulation of E-cadherin (78); and vii) targeting FOXL1 leading to activation of $\mathrm{Wnt} / \beta$-catenin signaling (79).

LncRNAs, with a length $>200$ nucleotides (nt), may act as oncogenes that promote $\mathrm{CRC}$ growth and are often upregulated in CRC $(25,62-67,73,84,86)$. The activation of the $\mathrm{Wnt} / \beta$-catenin signaling pathway is closely associated with the abnormal expression of IncRNAs in CRC (25) and this pathway is involved in IncRNA-mediated CRC progression (63). Accumulating evidence has shown that the aberrant expression of lncRNAs is strongly associated with the $\beta$-catenin-mediated upregulation of Wnt target genes. For example, lncRNAs promote 
Table I. Effects of ncRNAs on CRC in the Wnt/ $\beta$-catenin signaling pathway.

\begin{tabular}{|c|c|c|}
\hline NcRNAs & $\begin{array}{l}\text { Oncogene or } \\
\text { suppressor }\end{array}$ & $\begin{array}{l}\text { Biological effects on CRC } \\
\text { in the } \mathrm{Wnt} / \beta \text {-catenin signaling pathway }\end{array}$ \\
\hline $\operatorname{miR}-124$ & Suppressor & $\begin{array}{l}\text { Inhibits CRC cell proliferation, invasion and tumor growth, and induces apoptosis } \\
\text { via the interaction with PLCB1 and the regulation of the Wnt } 4 \text { signaling }\end{array}$ \\
\hline $\operatorname{miR}-410$ & Oncogene & $\begin{array}{l}\text { Downregulates DKK1, promotes CRC cell proliferation and invasion, inhibits } \\
\text { apoptosis, and increases the levels of } \beta \text {-catenin and phosphorylated GSK-3 } \beta\end{array}$ \\
\hline $\operatorname{miR}-490-3 p$ & Suppressor & $\begin{array}{l}\text { Inhibits the expression of FRAT1 and } \beta \text {-catenin, and suppresses CRC } \\
\text { progression and EMT }\end{array}$ \\
\hline $\operatorname{miR}-93$ & Suppressor & $\begin{array}{l}\text { Inhibits the viability, colony formation and migration of CRC cells, and } \\
\text { downregulates } \beta \text {-catenin and } \operatorname{Smad} 7\end{array}$ \\
\hline $\operatorname{miR}-155$ & Oncogene & $\begin{array}{l}\text { Promotes CRC cell proliferation and growth of CRC xenografts via HBP1- } \\
\text { mediated activation of the } \mathrm{Wnt} / \beta \text {-catenin signaling }\end{array}$ \\
\hline $\operatorname{miR}-199 \mathrm{a} / \mathrm{b}$ & Oncogene & $\begin{array}{l}\text { Mediatescisplatin-resistance of CRC stem cells via downregulation of GSK-3 } \beta \\
\text { and upregulation of } \beta \text {-catenin and ABCG } 2\end{array}$ \\
\hline $\operatorname{miR}-532-3 p$ & Suppressor & $\begin{array}{l}\text { Induces CRC cell apoptosis and downregulates } \beta \text {-catenin via directly targeting } \\
\text { ETS1 and TGM2 }\end{array}$ \\
\hline $\operatorname{miR}-19 a-3 p$ & Oncogene & 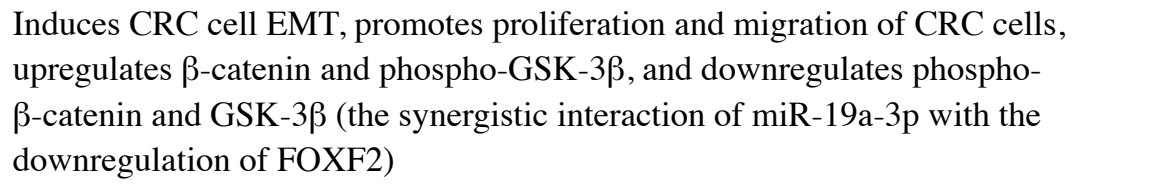 \\
\hline miR-188 & Oncogene & Promotes CRC cell proliferation, migration and invasion via targeting FOXL1 \\
\hline $\operatorname{miR}-377-3 p$ & Suppressor & $\begin{array}{l}\text { Suppresses CRC cell proliferation, migration and chemoresistance via targeting } \\
\text { ZEB2 and XIAP (two positive regulators of the } \mathrm{Wnt} / \beta \text {-catenin signaling) }\end{array}$ \\
\hline $\operatorname{miR}-144-3 p$ & Suppressor & $\begin{array}{l}\text { Suppresses CRC cell proliferation and progression, and downregulates } \beta \text {-catenin } \\
\text { via targeting BCL6 leading to downregulation of LRP6, FZD4, FZD8, LEF1 or } \\
\text { TCF7L2 }\end{array}$ \\
\hline LncRNA-01354 & Oncogene & Promotes CRC cell proliferation, migration, EMT, growth and metastasis \\
\hline LncRNA-NEAT1 & Oncogene & Promotes the expression of $\beta$-catenin \\
\hline LncRNA-SNHG1 & Oncogene & $\begin{array}{l}\text { Promotes the translocation of } \beta \text {-catenin into the nucleus, the gene expression of } \\
\text { TCF/LEF transcription factor and CRC cell proliferation, and inhibits apoptosis }\end{array}$ \\
\hline LncRNA-p21 & Suppressor & $\begin{array}{l}\text { Promotes the sensitivity of CRC radiotherapy, induces apoptosis, and reduces the } \\
\text { level of } \beta \text {-catenin }\end{array}$ \\
\hline LncRNA-CCAL & Oncogene & $\begin{array}{l}\text { Promotes the multidrug resistance of CRC cells via inhibiting AP- } 2 \alpha \text { expression } \\
\text { and upregulating MDR1/P-gp, increases histone H3 acetylation, and decreases } \\
\text { histone H3 methylation }\end{array}$ \\
\hline LncRNA-CASC11 & Oncogene & $\begin{array}{l}\text { Promotes CRC cell proliferation, metastasis and nuclear accumulation of } \beta \text {-catenin } \\
\text { via targeting hnRNP-K }\end{array}$ \\
\hline LncRNA-H19 & Oncogene & $\begin{array}{l}\text { Mediates methotrexate resistance via increasing the RNA levels of Wnt } \\
\text { downstream targets }\end{array}$ \\
\hline $\begin{array}{l}\text { LncRNA- } \\
\text { HNF1A-AS1 }\end{array}$ & Oncogene & Promotes the expression of $\beta$-catenin \\
\hline LncRNA-PART1 & Oncogene & $\begin{array}{l}\text { Promotes CRC cell proliferation and migration, and inhibits apoptosis functioning } \\
\text { as a ceRNA of miR-150-5p and miR-520h }\end{array}$ \\
\hline $\begin{array}{l}\text { LncRNA- } \\
\text { ARAP1-AS1 }\end{array}$ & Oncogene & Promotesthe EMT process in CRC cells via the ARAP1-AS1/YY1 axis \\
\hline $\begin{array}{l}\text { LncRNA-ROR1- } \\
\text { AS1 }\end{array}$ & Oncogene & $\begin{array}{l}\text { Isinvolved in CRC tumorigenesis, promotes CRC cell proliferation, and } \\
\text { upregulates the expression of } \beta \text {-catenin, Wnt3a, Survivin and } \mathrm{Wnt} 3 \mathrm{a}\end{array}$ \\
\hline LncRNA-00675 & Suppressor & $\begin{array}{l}\text { Inhibits CRC cell proliferation, invasion and migration via suppressing the } \\
\text { expression of miR-942, as well as upregulates GSK-3 } \beta\end{array}$ \\
\hline LncRNA-GAS5 & Suppressor & $\begin{array}{l}\text { Suppresses CRC cell invasion, migration, tumor growth and the expression of } \\
\beta \text {-catenin, as well as inhibits angiogenesis by decreasing microvascular density }\end{array}$ \\
\hline $\begin{array}{l}\text { LncRNA- } \\
\text { LINC00365 }\end{array}$ & Oncogene & $\begin{array}{l}\text { Downregulates GSK-3 } \beta \text {, upregulates } \beta \text {-catenin, inhibits CRC cell apoptosis, } \\
\text { and promotes CRC cell proliferation, migration and invasion }\end{array}$ \\
\hline
\end{tabular}

(Refs.) 
Table I. Continued.

\begin{tabular}{|c|c|c|c|}
\hline NcRNAs & $\begin{array}{l}\text { Oncogene or } \\
\text { suppressor }\end{array}$ & $\begin{array}{l}\text { Biological effects on CRC } \\
\text { in the } \mathrm{Wnt} / \beta \text {-catenin signaling pathway }\end{array}$ & (Refs.) \\
\hline LncRNA-NEAT1 & Oncogene & $\begin{array}{l}\text { Promotes CRC progression via acting as a ceRNA to sponge miR-486-5p, } \\
\text { activating the NR4A1/Wnt/ } / \text {-catenin pathway }\end{array}$ & $(89)$ \\
\hline LncRNA-AC010789.1 & Oncogene & $\begin{array}{l}\text { Promotes CRC progression and induces EMT via upregulating } \\
\text { miR-432-3p-dependent ZEB1, functioning as a ceRNA of miR-432-3p }\end{array}$ & $(65,90)$ \\
\hline LncRNA-HCG18 & Oncogene & $\begin{array}{l}\text { Promotes } \mathrm{CRC} \text { growth and invasion via sponging miR-1271 and subsequently } \\
\text { activating } \mathrm{MTDH} / \mathrm{Wnt} / \beta \text {-catenin signaling }\end{array}$ & $(66)$ \\
\hline LncRNA-UCID & Oncogene & Promotes CRC migration and invasion via sponging miR-152-3p & $(67)$ \\
\hline CircRNA-MBOAT2 & Oncogene & Promotes CRC cell proliferation and migration via sponging miR-519d-3p & $(91)$ \\
\hline CircRNA-0082182 & Oncogene & $\begin{array}{l}\text { Promotes CRC cell proliferation and metastasis, induces EMT, and inhibits } \\
\text { apoptosis via sponging miR-1205 and miR- } 411\end{array}$ & $(74)$ \\
\hline CircRNA-PDSS 1 & Oncogene & $\begin{array}{l}\text { Promotes migratory ability and angiogenesis leading to the lymphatic } \\
\text { metastasis and distant metastasis of CRC cells via upregulation of } \beta \text {-catenin }\end{array}$ & $(75)$ \\
\hline CircRNA-PRKDC & Oncogene & Promotes 5-FU resistance and invasion of CRC cells via targeting miR-375 & $(92)$ \\
\hline CircRNA-0005075 & Oncogene & Increases the expression levels of $\beta$-catenin, c-Myc and cyclin D1 in CRC cells & $(68)$ \\
\hline CircRNA-100290 & Oncogene & $\begin{array}{l}\text { Promotes CRC cell proliferation, migration and invasion, and inhibits } \\
\text { apoptosis via sponging miR-516b }\end{array}$ & (93) \\
\hline CircRNA-MTO1 & Suppressor & Inhibits growth and invasion of CRC cells, and downregulates $\beta$-catenin & (94) \\
\hline
\end{tabular}

the expression of cyclin D1, c-Myc $(25,62,73,82,85,88,95)$, CD44 (85), MMP-7 (62,73), Wnt3a (64), Oct3/4 (85) and Survivin (64). Apart from the upregulation of these Wnt target genes, certain lncRNAs are capable of increasing the expression levels of TCF/LEF transcription factor (73) and CDK1 (88). Additionally, the aberrant expression of lncRNAsis also able to downregulate GSK-3 $\beta(62,88)$. Certain lncRNAs promote CRC progression via sponging miRNAs, for example, lncRNA-HCG18 sponging miR-1271 (66) and lncRNA-UCID sponging miR-152-3p (67). LncRNAsact as competing endogenous RNAs (ceRNAs) to be involved inWnt/ $\beta$-catenin signaling via sponging miRNAs $(65,96)$, for example, lncRNA-PART1 sponging miR-150-5p/miR-520h (86) and lncRNA-NEAT1 sponging miR-486-5p (89). Selectively binding miRNAs by lncRNAs contributes to inhibiting their transcription and promoting their degradation and induces EMT of CRC cells $(63,72,90)$. In addition, those IncRNAs also promote the expression of nuclear $\beta$-catenin, cyclin D1, c-Myc, N-cadherin, vimentin, CD44, Jun and TCF1 via activating transcription factor and targeting miRNA, such as the lncRNA-ARAP1-AS1/YY1 (63) and lncRNA-AC010789.1/miR-432-3p/ZEB1 axes (90).

CircRNAs exhibit specific roles as the sponges of miRNAs (74). Additionally, numerous studies have reported that circRNAs as 'miRNA sponges' play a vital role in promoting $\mathrm{CRC}$ initiation and progression and inhibiting apoptosis $(74,94,97)$, for example, circRNA-MBOAT2 sponging miR-519d-3p (91), circRNA-0082182 sponging miR-1205 and miR-411 (74) and circRNA-100290 sponging miR-516b to promote FZD4 expression (93). The exact mechanisms of the functional roles of circRNA in CRC remain elusive. Additionally, the upregulation of circRNA-PDSS1 promotes migratory ability and angiogenesis in CRC cells via the upregulation of $\beta$-catenin, c-Myc, cyclin D1 and MMP-9, leading to lymphatic metastasis and distant metastasis (75).

Other abnormalities. The high levels of nuclear $\beta$-catenin and the defect of E-cadherin are founded in CRC (98). E-cadherin localized with $\beta$-catenin in the nucleus suppresses the LEF-1-mediated activation of the Wnt downstream target genes via recruiting $\beta$-catenin and prevents its nuclear localization, leading to inhibiting the interaction between $\beta$-catenin and LEF-1 (99). Another study also reported that the loss of E-cadherin leads to the accumulation of free $\beta$-catenin in the cytoplasm and promotes its interaction with LEF-1 (100). Additionally, other abnormalities in Wnt/ $\beta$-catenin signaling also aberrantly activate this pathway to promote CRC growth and metastasis. The aberrant expression of FZDs is associated with tumorigenesis, particularly in CRC (3). The upregulation of DVL has also been reported to activate $\mathrm{Wnt} / \beta$-catenin signaling in CRC (15). 


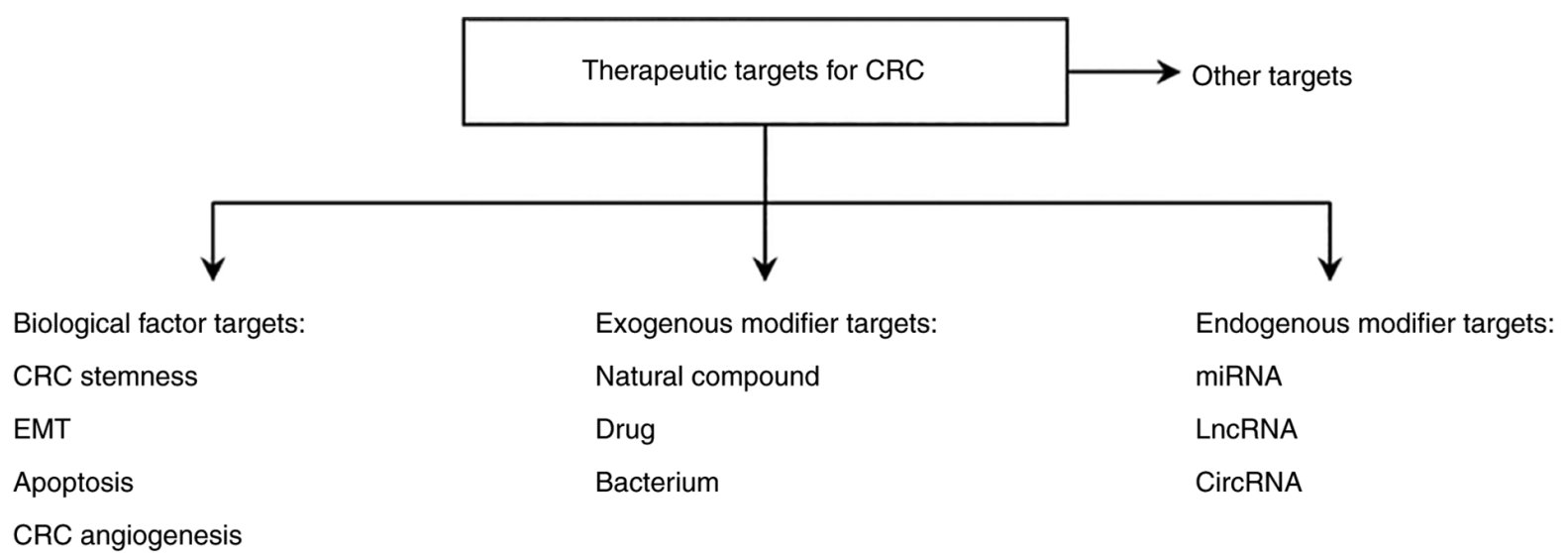

Figure 2. Wnt/ $\beta$-catenin signaling-associated therapeutic targets for colorectal cancer. CRC, colorectal cancer; EMT, epithelial-mesenchymal transition; lncRNA, long non-coding RNA; miRNA, microRNA; circRNA, circular RNA.

\section{Therapeutic strategies targeting Wnt/ $\beta$-catenin signaling for CRC}

Currently, common therapies for CRC mainly include surgical removal of the carcinoma, chemotherapy and radiotherapy. The conventional treatment strategy for patients with $\mathrm{CRC}$ is the surgical removal of the CRC tumor combined with chemotherapy (92). The main chemotherapeutic drugs for CRC include oxaliplatin, irinotecan and 5-fluorouracil (5-FU) (101). 5-FU is the most commonly used standard drug for CRC chemotherapy (92). Radiotherapy remains a major adjuvant therapy for patients with advanced CRC. Therefore, improved understanding of the molecular mechanism of the development and progression of CRC may contribute towards the development of drugs to prevent the migration and invasion of CRC cells and aid in the identification of novel therapeutic targets and effective diagnostic and prognostic indicators. CRC is associated with the aberrant activation of the $\mathrm{Wnt} / \beta$-catenin signaling pathway due to a combination of factors, therefore, in the present review, therapeutic targets for CRC are mainly divided into four categories, as summarized in Fig. 2.

\section{Biological factor-associated targets}

CRC stemness-associated therapeutic targets. A number of researchers have studied the interaction between CRC stem cell markers and Wnt/ $\beta$-catenin signaling. Chen et al found that phenethyl isothiocyanate (PEITC) is an effective inhibitor of CRC stem cells by targeting Wnt/ $\beta$-catenin signaling (44). In CRC stem cells treated with PEITC, decreased phosphorylated-GSK-3 $\beta$, nuclear $\beta$-catenin, and CD133 were observed. Diallyl trisulfide inhibits CRC stem cells by promoting the expression of GSK-3 $\beta$ and inhibiting the expression of $\beta$-catenin and CRC stem cell markers in CRC stem cells (49). IC-2, a derivative of $\mathrm{Wnt} / \beta$-catenin signaling inhibitor ICG-001, inhibits the expression of CRC stem cell marker proteins, as well as the sphere formation activity of CRC cells (102). ICG-001 promotes cell differentiation, suppresses cell proliferation, and induces apoptosis via binding to CREB-binding protein in CRC cells $(103,104)$, suggesting that IC-2 may also bind to this protein to suppress the sphere formation of CRC cells via inhibition of the expression of CRC stem cell markers.
However, some proteins drive CRC cell stemness by activating this pathway. For example, transmembrane 4 L6 family member 1 , a tumor-associated antigen, promotes invasion, tumorigenesis, recurrence and metastasis via the upregulation of stemness markers, N-cadherin, MMP-7, MMP-9, Smad2, vimentin, c-Myc, Axin2 and TCF7, and the downregulation of E-cadherin $(6,105)$. A recent study reported that human anterior gradient-2 (AGR2, an oncogene) activates the non-canonical Wnt signaling pathway via the upregulation of Wnt 11, and subsequently promotes the migration of CRC cells (106). Later, Dahal Lamichane et al studied the effect of AGR2 on spheroids containing CRC stem-like cells via the activated canonical Wnt signaling pathway (50). Their study revealed that AGR2 is upregulated in CRC, and promotes the expression of CRC stem cell markers. Another oncogene, inhibitor of differentiation/DNA binding 1 (Id-1) is upregulated in CRC, and patients with CRC with lymph node metastasis have a higher level of Id-1 expression than those without lymph node metastasis (107). Id-1 expression is strongly associated with CD133 expression, and Id-1 promotes CRC stem cell-like capacity and induces EMT, partially via activating the Wnt $/ \beta$-catenin and sonic hedgehog protein signaling pathways (42). Anterior gradient 3 (AGR3) is also upregulated in CRC, and silencing of AGR3 decreases nuclear $\beta$-catenin and inhibits the expression of CRC stem cell markers in CRC cells (45).

EMT-associated therapeutic targets. Qi et al identified three novel Wnt/ $\beta$-catenin/TCF4 target genes, nuclear factor interleukin-3-regulated protein, cyclin-dependent kinases regulatory subunit 2 , and ribosome biogenesis protein BOP1, which inhibit E-cadherin expression and increase the expression levels of vimentin, fibronectin and $\mathrm{N}$-cadherin (56). Additionally, accumulating evidence has shown that certain genes that promote the expression of EMT markers are upregulated in CRC, and their dysregulation is strongly associated with CRC via activating Wnt/ $\beta$-catenin signaling, such as tumor suppressor candidate 3 (57), cell migration-inducing hyaluronan binding protein (12), human rhomboid family-1 gene (58), ubiquitin-like modifier activating enzyme 2 (108), stromal cell-derived factor (109) and runt-related transcription factor 1 (71). Their overexpression promotes the expression of 
$\beta$-catenin $(57,71,108,109)$, Snail $(12,71), C D 44(71), c-M y c(58,71)$, MMP-2 (108), Met (71), MMP-7 (108), c-Jun (71), MMP-9 (108), MMP-14 (58), TCF-1/7 (71,108), vimentin (12,57,71,108,109), ZO-1 (12), LEF1 (71), N-cadherin $(12,71,109)$, phosphorylated-GSK-3 $\beta(58,108)$, Twist (58), ZEB1 (71) and cyclinD1 $(58,71)$, and inhibits the expression of GSK-3 $\beta(57,58)$, E-cadherin (12,57,71,108,109), APC (58) and Axin-2 (58).

Compared with the aforementioned EMT-associated therapeutic targets, two lncRNAs exhibit an inhibitory effect on CRC EMT by targeting Wnt/ $\beta$-catenin signaling $(55,110)$. LncRNA-CTD903 overexpression inhibits the expression of Snail, Twist and vimentin, and upregulates ZO-1 in CRC cells (55). LncRNA-KIAA0125 overexpression inhibits $\beta$-catenin at both the mRNA and protein levels, as well as cyclin D1 and myc at the protein level in CRC cells (110). Similarly, GTPase-activating protein for Rac and SRY-box transcription factor 15 also suppress CRC EMT and tumor growth via the upregulation of E-cadherin and the downregulation of vimentin, Snail, Twist1, ZEB1, free $\beta$-catenin, cyclin D1, c-Myc, MMP-2, MMP-7 and MMP-9 in CRC cells $(1,17)$. Among these negative regulators, they exhibit a similar ability to inactivate the Wnt/ $\beta$-catenin signaling pathway. Notably, compared with other negative regulators, IncRNA-KIAA0125 inactivates this pathway independently of E-cadherin expression (110). These findings indicated that the loss of E-cadherin is not essential for the activation of the $\mathrm{Wnt} / \beta$-catenin signaling pathway, since other components in this pathway, such as Axin or APC, also promote $\beta$-catenin nuclear translocation to induce EMT (54). This result provided additional evidence that the activation of $\mathrm{Wnt} / \beta$-catenin signaling may be independent of the loss of E-cadherin. However, the underlying molecular mechanisms remain unclear.

Apoptosis-associated therapeutic targets. ICG-001, a small molecule inhibitor, induces the apoptosis of the colon carcinoma cells and inhibits the growth of the colon cancer cells via the downregulation of TCF/ $\beta$-catenin (103). Survivin, an inhibitor of apoptosis, is highly expressed in cancers and it is reported that $\mathrm{TCF} / \beta$-catenin participates in the regulation of the survivin transcription and expression in colon cancers (104). Therefore, the disruption of $\mathrm{TCF} / \beta$-catenin signaling is a promising means for early chemopreventive intervention to CRC. ICG-001-mediated inhibition of the survivin expression increases caspase-3 (a key enzyme of apoptosis) activity, promotes cell differentiation, suppresses cell proliferation and induces apoptosis via enhancing p300 (histone acetylase) $/ \beta$-catenin interaction at the expense of $\mathrm{CBP} / \beta$-catenin $(103,104,111)$. Trials with the second generation $\mathrm{CBP} / \beta$-catenin inhibitor PRI-724 are underway for patients with refractory CRC (112). PRI-724 is still in clinical trials (27) and it may become a therapy for CRC. The treatment of the cancer stem cells with $\mathrm{CBP} / \beta$-catenin inhibitors promotes them to undergo differentiative divisions and subsequently clears cancer stem cells from the niche (112). Collectively, these studies indicated that $\mathrm{Wnt} / \beta$-catenin signaling is related to $\mathrm{CBP} / \beta$-catenin signaling and p300/ $\beta$-catenin signaling, with $C B P / \beta$-catenin interaction promoting CRC cell proliferation, however p300/ $\beta$-catenin interaction facilitates CRC cell differentiation and, possibly, apoptosis.
Due to the biological characteristics of two histone acetylases (CBP and p300) in CRC, an increasing number of experts have focused on the effects of histone deacetylases (HDAC) on CRC. Histone acetylases and HDACs are involved in the maintenance of the balance between histone acetylation and deacetylation. The interaction between $\beta$-catenin and histone acetylases (CBP and p300) influences Wnt/ $\beta$-catenin signaling and colorectal cell physiology (28). Therefore, HDAC inhibitors may affect CBP and p300 to induce apoptosis via regulating Wnt/ $\beta$-catenin signaling (27).

Butyrate (a HDAC inhibitor and short-chain fatty acid) is produced by the bacterial fermentation of the dietary fiber (113). In populations with low dietary fiber intake, a doubling of the total dietary fiber intake may reduce the risk of CRC by $40 \%$ (114). Therefore, certain researchers extended their studies to butyrate and investigated whether butyrate also induces apoptosis. Studies found that butyrate induces CRC apoptosis, cell cycle arrest and differentiation and regulates Wnt/ $\beta$-catenin signaling activity in CRC cells $(27,28,113,115-117)$. In addition, trichostatin $\mathrm{A}$, a more selective inhibitor of HDAC, is also capable of inducing apoptosis in CRC cells (118). HDAC inhibitor-induced Wnt/ $\beta$-catenin hyperactivation and CRC cell apoptosis may partly explain the preventive function of the dietary fiber against CRC (27,116). Similarly, other studies also reported that the dysregulated $\mathrm{Wnt} / \beta$-catenin signaling pathway in moderate activity levels induces CRC cell proliferation and carcinogenesis, however relatively high levels of this pathway lead to increasing cell apoptosis and decreasing cell proliferation in CRC $(27,115,119)$. Additionally, accumulating evidence indicates that there is a linear relationship between the increase in $\beta$-catenin transcriptional activity and the level of the apoptosis in CRC cells treated with butyrate $(114,119)$. Another study proposed that butyrate inhibits HDAC leading to chromatin relaxation and the changes of the chromatin structure, which promotes the activation of caspase- 3 by mitochondria and triggers the apoptosis of CRC cells (118).

Angiogenesis-associated therapeutic targets. The dual actions of angiogenic and anti-apoptotic processes are critical for CRC tumor growth (87). Yang et al reported the effect of the oncogene tissue transglutaminase (TGM2) on the angiogenesis and apoptosis of CRC via activating Wnt/ $\beta$-catenin signaling (120). It was revealed that the downregulation of TGM2 inhibits angiogenesis and the expression of $\beta$-catenin, Wnt3a, MMP-2, MMP-9 and cyclin D1, whereas its downregulation promotes the expression of TIMP-1 and caspase-3 and apoptosis in TGM2-siRNA-transfected CRC cells. Caspase-3 is a key enzyme of apoptosis (111), and invasion-associated proteins (MMP-2 and MMP-9) (2) and TIMP-1 are involved in tumor invasion and metastasis via angiogenesis (121). These results indicated that TGM2 is able to effectively promote the angiogenesis and inhibits apoptosis via activating the $\mathrm{Wnt} / \beta$-catenin signaling pathway in CRC cells.

\section{Exogenous modifier-associated targets}

Natural compounds as therapeutic targets. Numerous phytochemicals derived from edible plants have been reported to inhibit tumorigenesis. A number of mechanisms have been shown to contribute to the anti-carcinogenic actions of 
phytochemicals (122), and more attention has been focused on the Wnt/ $\beta$-catenin signaling pathway as a target for phytochemicals. In recentyears, natural compounds have been intensively screened for this pathway sincethese compounds are involved in the regulation of Wnt signaling and they are in our diet (123). Vitamin D3 plays its physiological role via the active metabolite 1,25-(OH)2D3, and vitamin D deficiency is associated with CRC (124). Ligand-activated vitamin D receptors compete with TCF-4 for $\beta$-catenin binding, accordingly, vitamin D3 inhibits $\beta$-catenin/TCF-4 transcriptional activity, leading to the downregulation of $\beta$-catenin/TCF-4 target genes, including c-Myc, Tcf-1 and CD44 (98). These contribute to promoting the differentiation of colon cancer cells. 24-Hydroxylase is upregulated in CRC cells, and its inhibition promotes the antitumor effects of $1,25-(\mathrm{OH}) 2 \mathrm{D} 3$ via inducing the translocation of $\beta$-catenin from the nucleus to the plasma membrane and enhancing the inhibitory effect of 1, 25-(OH)2D3 on c-Myc (124). At present, a phase III study (trial no. NCT03389659) exploring the effect of vitamin D3 in combination with XELOX/mFOLFOX as first-line chemotherapy in untreated advanced or metastatic CRC is in progress (15).

Flavonoids are polyphenolic compounds with low toxic effects and are divided into four subclasses: i) chalcones; ii) flavanones; iii) flavones; and iv) flavonols (11). Evidence from case-control studies has demonstrated that flavonoids have a protective role against CRC (122). A previous study has indicated that flavonoids are capable of acting on different components of the Wnt $/ \beta$-catenin signaling pathway, such as $\beta$-catenin/TCF/LEF, segment polarity protein disheveled homolog DVL-1 (DVL1) and GSK-3 $\beta$ (123). Among the various types of flavonoids, quercetin is one of the most studied flavonoids with Wnt-inhibitory properties and has been submitted to clinical trials (123). Quercetin has been highlighted as a potential anti-CRC drug, and the effect of quercetin on CRC growth is strongly associated with Wnt/ $\beta$-catenin signaling (11). Quercetin may interact with $\beta$-catenin and inhibit the binding of $\beta$-catenin to TCF, leading to the inactivation of the $\mathrm{Wnt} / \beta$-catenin signaling pathway in CRC cells in vitro $(125,126)$. Another extensively studied anticancer flavonoid is the green tea compound epigallocatechin 3-gallate (EGCG), which inhibits the Wnt/ $\beta$-catenin signaling pathway in CRC cells (126). The underlying mechanism by which EGCG functions on this pathway is that EGCG targets Wnt inhibitory factor 1 (WIF-1) and promotes its expression via demethylation, leading to the inactivation of Wnt $/ \beta$-catenin signaling via the direct binding of WIF-1 to Wnt molecules (11). Other studies suggested that EGCG inhibits CRC cell proliferation in the APC ${ }^{\min /+}$ mouse model for intestinal tumorigenesis via suppressing the expression of nuclear $\beta$-catenin, indicating the inhibitory effect of EGCG on the translocation of $\beta$-catenin to the nucleus $(127,128)$. Silibinin, another natural polyphenolic flavonoid, inhibits CRC cell proliferation, induces apoptosis and reduces nuclear levels of $\beta$-catenin in SW480 cells harboring a mutation in APC, but not in HCT 116 cells harboring a $\beta$-catenin mutation and wild-type APC, indicating the selective effect of silibinin on Wnt/ $\beta$-catenin signaling (129). Additionally, silibinin also inhibits the expression of cyclin D1 via the downregulation of cyclin-dependent kinase 8 (CDK8, a CRC oncoprotein that promotes $\beta$-catenin activity), leading to the inhibition of the growth of SW480 tumors (129). Wogonin, a naturally occurring mono-flavonoid isolated from Scutellaria radix, inhibits the expression of Wnt3A, c-Myc, LRP6 and cyclin D1, suppresses the kinase activity of CDK8, and promotes the expression of Axin1 in HCT116 cells, leading to the inhibition of CRC cell proliferation (130). Genistein, an isoflavonoid derived from soy products, is capable of inhibiting the transcriptional activity of $\beta$-catenin/TCF in SW480 cells via promoting the phosphorylation of $\beta$-catenin by GSK-3 $\beta$ (11). Genistein has been tested in a phase I-II clinical trial in combination with FOLFOX or FOLFOX-Avastin to reduce chemotherapy resistance and improve response rates for stage IV CRC (trail no. NCT01985763) (15). Lonchocarpin, a chalcone isolated from Lonchocarpus sericeus, blocks the nuclear localization of $\beta$-catenin, and constitutively inhibits TCF4 activity, thus suppressing CRC cell proliferation and migration in SW480, HCT116 and DLD-1 cells (131).

N-3 polyunsaturated fatty acids (N-3 PUFAs), which regulate several signaling pathways, potentiate the effects of radiotherapy, however the molecular mechanisms through which N-3 PUFAs enhance the anti-carcinogenic effects of this therapy in CRC treatment remain unclear (19). Radiotherapy is an adjuvant therapy for patients with advanced CRC, although the fractionation schedules for the treatment of CRC frequently result in the repopulation of surviving CRC cells, progression and metastasis (132). The acquired radioresistance of surviving CRC cells shows an adaptive status in which CRC progression and evasion of cell death are increased. Docosahexaenoic acid (DHA, one of the main N-3 PUFA family members) promotes cell cycle arrest, and inhibits the effects of irradiation on cell proliferation in CRC cells exposed to $\gamma$-radiation via reducing GSK- $3 \beta$ phosphorylation and inhibiting irradiation-triggered nuclear translocation of $\beta$-catenin and subsequently the expression of cyclin D1 (19).

Sanguisorba officinalis has been used as a herbal medicine for a number of years in China, Japan and Korea, and has broad biological activities, including antioxidant, anti-inflammatory and anticancer activities (133). Sanguisorba officinalis exhibits strong anti-proliferative activities against CRC cells (33). Liu et al further studied the inhibitory effect of tannins extracted from Sanguisorba officinalis on CRC cells (134). Their study revealed that Sanguisorba officinalis and its tannins inhibit the expression of $\beta$-catenin, cyclinD1, c-Myc and Axin2, while decreased mRNA levels of lysophosphatidic acid receptor 6 may be associated with the inhibitory effects of Sanguisorba officinalis and its tannins on CRC cells. Later, Li et al investigated the underlying molecular mechanism of Sanguisorba officinalis against Wnt/ $\beta$-catenin signaling leading to apoptosis in CRC cells (33). They discovered that 1, 4, 6-Tri- $O$-galloyl- $\beta$-D-glucopyranose (a tannin compound from Sanguisorba officinalis) downregulates the expression of $\beta$-catenin, Survivin, and c-Myc, and upregulates the expression of caspase-3 in CRC cells, indicating the inactivation of the Wnt/ $\beta$-catenin signaling pathway. Survivin is an inhibitor of apoptosis (19) and caspase-3 is a key enzyme of apoptosis (111), which may explain the apoptosis of CRC cells via inhibition of Wnt//-catenin signaling by Sanguisorba officinalis.

In addition to the aforementioned natural compounds, certain other extractions from natural products also inhibit 
CRC growth and induce CRC cell apoptosis via inactivation of the Wnt/ $\beta$-catenin signaling pathway. Their inhibitory mechanisms in this pathway mainly include: i) Downregulating the levels of $\beta$-catenin or inhibiting nuclear translocation of $\beta$-catenin, such as TKP extracted from a medicinal plant Trichosanthes kirilowii (2), magnolol derived from Magnolia obovata (135), ethanol extract of Scutellaria barbata D. Don (EESB) (136), jatrorrhizine (a main component of Rhizoma coptidis) (46) and pristimerin (a natural triterpenoid) (137); ii) downregulating phosphosylated-GSK-3 $\beta$ or upregulating GSK-3 $\beta$, for example TKP (138); iii) inhibiting the expression of Wnt downstream target genes, including magnolol (135), EESB (136), sulforaphane extracted from cruciferous vegetables (18) and pristimerin (137); iv) blocking the interaction between $\beta$-catenin and TCF4 complexes, such as magnolol (135) and $11 \alpha, 12 \alpha$-epoxyleukamenin E isolated from Salvia cavaleriei (37); v) downregulating invasion-associated proteins MMP-2 and MMP-9, such as TKP (138); vi) inhibiting EMT via increasing E-cadherin and decreasing N-cadherin, such as jatrorrhizine (46); and vii) exerting a synergistic effect on the inhibition of $\mathrm{CRC}$, for example, the combination of cucurbitacin $\mathrm{E}$ and 5-FU inhibits the expression of $\beta$-catenin and chemosensitizes $\mathrm{CRC}$ cells via negatively regulating the transcription factor AP4/Wnt/ $\beta$-catenin axis (139).

Aloe vera has been used as a herbal remedy to treat constipation and promote digestion $(140,141)$. However, several studies have suggested an association between Aloe vera and the development of CRC $(140,142,143)$. Among the components of aqueous extract from Aloe vera, aloesin and aloin may have potential functions in promoting $\mathrm{CRC}$ tumorigenesis via activating Wnt/ $\beta$-catenin signaling $(144,145)$. Dai et al found that the aqueous extract of Aloe vera at concentrations between $0.98-12.50 \mu \mathrm{g} \mathrm{ml}^{-1}$ promotes the expression of active $\beta$-catenin, DKK1 and Axin2, indicating that Aloe verais capable of activating this signaling pathway at a low concentration (145). The crosstalk between the Wnt/ $\beta$-catenin and the Notch signaling pathways has been known to be strongly associated with CRC tumorigenesis and cell proliferation (146). Therefore, the effects of Aloe vera on these two pathways and the proliferation of CRC cells have been studied. In the presence of Wnt3a, the aqueous extract of Aloe vera at a concentration of $33.3 \mu \mathrm{g} / \mathrm{ml}$ promotes CRC cell proliferation, and aloin activates Wnt/ $\beta$-catenin signaling and inhibits Notch signaling (144). However, in the absence of Wnt3a, aloesin directly activates the Wnt/ $\beta$-catenin signaling pathway and suppresses Notch signaling (144). These results do not support the possibility that there is crosstalk between the Wnt/ $\beta$-catenin and Notch pathways in CRC cell proliferation (146). Recently, a study explored the potential mechanism of the carcinogenic activity of Aloe verain CRC at the post-transcriptional level, and found that Aloe veramay contribute to the regulation of the alternative splicing of Notch-related genes and Wnt/ $\beta$-catenin-related genes, such as $\beta$-catenin, FZD6, LEF1, DVL1, Axin2, Myc and TCF7L2 (141).

Drug-associated therapeutic targets. 5-FU is the commonly used standard drug for CRC chemotherapy $(92,147)$. Recently, the synergistic effects of 5-FU with other drugs on the $\mathrm{Wnt} / \beta$-catenin pathway in CRC cells have been studied. Studies revealed that although 5 -FU initially reduces the size of the
CRC tumor, resistance (101) and recurrence (47) following chemotherapy prevent favorable clinical outcomes for patients with CRC. Additionally, typical patient response rates for 5-FU are between 10 and 30\% (148). Therefore, numerous studies have investigated the interaction between $5-\mathrm{FU}$ resistance and the $\mathrm{Wnt} / \beta$-catenin pathway in 5-FU-resistant CRC cells. CircRNA-PRKDC promotes 5-FU resistance and CRC cell invasion via activating this pathway (92). A previous study reported that 5-FU activates tumor suppressor p53 via RNA damage or DNA damage of tumor cells (149). Adenovirus-mediated transfer of wild-type p53 gene markedly reverses 5-FU resistance and inhibits the high expression of multidrug resistance gene-1 in multidrug-resistant human CRC LoVo/5-FU cells (150). However, compared with these prior results, another study suggested that 5-FU activates the $\mathrm{Wnt} / \beta$-catenin pathway and enriches CRC stem cells in tumor organoids derived from $\mathrm{APC}^{\mathrm{min} /+} / \mathrm{Lgr} 5 \mathrm{EGFP}$ mice, leading to recurrence following treatment with 5-FU, via promoting Wnt3 transcription by p53 (47). Therefore, the promoting effect of 5-FU on CRC stemness via the activation of p53-mediated Wnt/ $\beta$-catenin signaling may contribute to recurrence following initial chemical debulking of CRC tumor cells treated with 5-FU.

Cisplatin (DDP) is another common drug for CRC chemotherapy (148). Similar to 5-FU, DDP chemoresistance frequently occurs in patients with CRC (151). Fibroblast growth factor 9 (FGF9) is upregulated in CRC and is associated with poor clinical outcome in patients with CRC (152). FGF9 upregulation contributes to the development of DDP resistance via the inhibition of APC expression and promotion of $\beta$-catenin expression in CRC cells (151). Tankyrase 1 inhibitor XAV939, a small molecule inhibitor of the Wnt/ $\beta$-catenin pathway, increases chemosensitivity in CRC cells treated with 5-FU/DDP, combined with the upregulation of Axin and the downregulation of $\beta$-catenin (148). A study reported that the overexpression of Golgi phosphorylated protein 3 (GOLPH3) in CRC tissue could promote CRC proliferation and inhibit apoptosis, combined with the upregulation of $\beta$-catenin (153). GOLPH3 overexpression also promotes Wnt $/ \beta$-catenin-mediated DDP resistance in CRC cells treated with $10 \mu \mathrm{M}$ DDP (147). Therefore, GOLPH3 and FGF9 should be the focus of future research on DDP resistance. Additionally, pimozide has also been considered as a potential anticancer drug and has exhibited satisfactory results in CRC. Furthermore, it is able to inhibit EMT via the inactivation of the Wnt/ $\beta$-catenin signaling pathway (154). Another study demonstrated that pimozide downregulates the expression of $\beta$-catenin, Axin 2, cyclin D1 and c-Myc, and subsequently inhibits EMT through the upregulation of E-cadherin and the downregulation of N-cadherin, Snail and vimentin (59). These studies indicated that the inhibitory effect of pimozide on CRC results from the suppression of EMT.

Bacterium-associated therapeutic targets. Certain studies have reported that Fusobacterium nucleatum, an anaerobic Gram-negative oral commensal bacterium, is important in CRC tumorigenesis and is often associated with metastasis, chemo-resistance and poor prognosis $(53,155-157)$. A previous study has suggested that Fusobacterium nucleatum is present in CRC and adheres to and invades intestinal epithelial cells 
mainly via virulence factors, such as Fusobacterium adhesin A (FadA) (53). Rubinstein et al investigated the mechanism by which Fusobacterium nucleatum promotes CRC tumorigenesis via its FadA adhesin (155). It was revealed that FadA activates Wnt/ $\beta$-catenin signaling via inducing $\beta$-catenin-mediated transcription and regulates oncogenic and inflammatory responses, leading to CRC tumorigenesis due to Fusobacterium nucleatum. Later, Rubinstein et al further researched the effect of the interaction between FadA and Annexin A1 (a Wnt/ $\beta$-catenin signaling modulator) on tumor growth in CRC cells infected by Fusobacterium nucleatum (156). It was revealed that Fusobacterium nucleatum combined with Annexin A1 and $\beta$-catenin preferentially binds to CRC cells leading to the upregulation of cyclin D1. However, Ma et al suggested that Fusobacterium nucleatum interacts with E-cadherin leading to EMT instead of $\beta$-catenin, which subsequently promotes the malignant phenotype of CRC cells (53). Another study showed that Fusobacterium nucleatum promotes CRC tumor growth via cyclin-dependent kinase 5 (Cdk5)-activated Wnt/ $\beta$-catenin signaling and the Cdk5-mediated upregulation of $\beta$-catenin, cyclin D1 and c-Myc (157). Lactobacillus species, another bacterium, inhibits CRC progression via the upregulation of GSK-3 $\beta$, as well as the downregulation of the Wnt/ $\beta$-catenin-related genes, such as Axin-2, CTNNB1, cyclin D1, pygopus family PHD finger 2 and inhibitor of DNA binding 2 (158). The results may provide insights into the development of the novel antimicrobial therapy targets for CRC.

\section{Endogenous modifier-associated targets}

miRNAs as therapeutic targets. miRNAs may function as tumor suppressors. As revealed in Table I, overexpression of miR-377-3p suppresses CRC cell proliferation, migration and chemoresistance via targeting two positive regulators of the Wnt/ $\beta$-catenin signaling pathway, ZEB2 and E3 ubiquitin-protein ligase XIAP (80). miR-144-3p inhibits CRC cell proliferation and progression via the targeting of $B$ cell lymphoma 6 protein to LRP6, FZD4, FZD8, LEF1 and TCF7L2 (81,159). miR-490-3p inhibits the expression ofproto-oncogeneFRAT1 (a GSK-3-binding protein), CRC progression and EMT (76). miR-532-3p directly targets the protein ETS1/TGM2 axis and activates apoptosis signaling, and upregulates apoptosis-related proteins, such as cleaved (c)-caspase-3, c-caspase-7 and c-caspase-9 (77). miR-93 inhibits Smad7 expression, which contributes to preventing the nuclear accumulation of $\beta$-catenin and subsequently suppresses CRC cell viability, colony formation and migration (36). Among miRNAsas tumor suppressors, some also inhibit the expression of $\beta$-catenin $(36,77,81), \operatorname{Smad} 7$ (36) and Wnt target genes, such as CD44 (77), c-Myc (36,77,81), MET (77), cyclin D1 $(36,81)$ and c-Jun $(77)$, while promoting the expression of Axin (36). The downregulation of Wnt target genes and $\beta$-catenin, and the upregulation of Axin contribute to the inactivation of $\mathrm{Wnt} / \beta$-catenin signaling and subsequently inhibit CRC tumorigenesis and metastasis. Notably, miR-124 inhibits CRC cell proliferation and invasion, and inducesapoptosisvia the interaction with 1-phosphatidylinositol 4,5-bisphosphate phosphodiesterase b-1 and upregulation of Wnt4 (7). However, another study suggested that Wnt4 secreted by CRC tissues promotes CRC progression via EMTandangiogenesis (31). Therefore, under different circumstances, the effect of Wnt4 on CRC may be inhibitory or promoting. The aforementioned studies indicate that miRNAs acting as tumor suppressors broadly interact with other regulators and reveals the complexity of gene regulation.

LncRNAs as therapeutic targets. Certain lncRNAs also function as safeguards against CRC growth via inhibiting CRC cell proliferation, inducing apoptosis and promoting the expression of tumor suppressors. Wang et al reported that apoptosis was detected after lincRNA-p21-overexpressing CRC cells were treated with X-rays, which indicated that the overexpression of lincRNA-p21 promotes the sensitivity of CRC radiotherapy by inducing the apoptosis of CRC cells (83). The overexpression of lncRNA-00675 inhibits the proliferation, invasion and migration of CRC cells via suppressing the expression of miR-942, which is upregulated in clinical CRC tissues (8). Another lncRNA, IncRNA-GAS5, suppresses CRC cell invasion, migration and tumor growth, as well as angiogenesis by lowering microvascular density (87). LincRNA-p21 decreases the expression levels of $\beta$-catenin and c-Myc, which leads to the inactivation of the $\mathrm{Wnt} / \beta$-catenin signaling pathway. Similar regulatory mechanisms also exist for lncRNA-00675 and lncRNA-GAS5. These results indicated that lncRNAs acting as tumor suppressors inhibit CRC growth via inactivating this pathway.

CircRNAs as therapeutic targets. CircRNAs also act as tumor suppressors and inhibit CRC growth and invasion via inactivating $\mathrm{Wnt} / \beta$-catenin signaling. For example, circRNA-MTO1 inhibits the growth and invasion of CRC cells via the downregulation of $\beta$-catenin, cyclin D1 and c-Myc (94). However, compared with miRNAs, the proportion of circRNAs acting as suppressors is relatively low. As revealed in Table I, for miRNAs, suppressors account for $54.55 \%$ (6/11), lncRNAs, $16.67 \%(3 / 18)$ and circRNAs, only $14.29 \%(1 / 7)$. Therefore, compared with miRNAs, IncRNAs and circRNAs mainly exert promoting effects on $\mathrm{CRC}$ via activating $\mathrm{Wnt} / \beta$-catenin signaling.

Other targets for CRC therapy. In addition to the aforementioned studies, researchers have found several other Wnt/ $\beta$-catenin signaling-associated targets for CRC therapy. These targets include functional oncogenes (160-162), epidermal growth factor-like proteins (163), adaptor proteins (4), stomatin-like proteins (164), chromatin organizers (165), antioxidants (166), and architectural transcription factors (105), which promote CRC growth via activating Wnt/ $\beta$-catenin signaling. Additionally, negative regulatory targets inhibit CRC progression via inactivating Wnt/ $\beta$-catenin signaling, and these targets include tumor suppressor genes $(167,168)$, metastasis-suppressor genes (169), ubiquitin-like proteins (170) and anticancer bioactive peptides (171). In the present review, the effects of these therapy targets on CRC in the Wnt/ $\beta$-catenin signaling pathway are presented in Table II $(3,4,21,35,52,60,105,160-178)$.

\section{Challenges in targeting Wnt/ $\beta$-catenin signaling in CRC}

Aberrant $\mathrm{Wnt} / \beta$-catenin signaling is known to drive CRC tumorigenesis. However, it remains unclear whether this 
Table II. Other Wnt/ $\beta$-catenin signaling-associatedtargets for CRC therapy.

\begin{tabular}{|c|c|c|c|c|}
\hline Agents & Targets & Dysregulation & Biological effects on $\mathrm{CRC}$ in the $\mathrm{Wnt} / \beta$-catenin signaling pathway & (Refs.) \\
\hline NPTX2 & FZD6 & Upregulation & Promotes CRC cell proliferation and metastasis & (3) \\
\hline EGFL6 & $\mathrm{TCF}$ & Upregulation & $\begin{array}{l}\text { Promotes the interaction of } \mathrm{CBP} \text {-mediated } \mathrm{TCF} / \beta \text {-catenin and } \\
\text { subsequently colorectal tumorigenesis }\end{array}$ & $(163)$ \\
\hline$(\mathrm{P}) \mathrm{RR}$ & Wnt3, LRP6 & Upregulation & $\begin{array}{l}\text { Upregulates Wnt3a and LRP6, promotes CRC cell proliferation } \\
\text { and tumor growth, and inhibits CRC apoptosis }\end{array}$ & (4) \\
\hline SLP-2 & GSK-3 $\beta$ & Upregulation & $\begin{array}{l}\text { Downregulates GSK-3 } \beta \text {, promotes CRC cell migration, invasion } \\
\text { and metastasis, and predicts the poor prognosis }\end{array}$ & $(164)$ \\
\hline NUP153 & LEF1 & Downregulation & $\begin{array}{l}\text { Upregulates LEF1, inhibits CRC proliferation, and predicts } \\
\text { favorable prognosis }\end{array}$ & $(35)$ \\
\hline SATB1 & TCF7L2 & Upregulation & $\begin{array}{l}\text { Promotes } \beta \text {-catenin/TCF712-mediated transcription, initiates CRC } \\
\text { tumorigenesis, and predicts the poor prognosis }\end{array}$ & $(165,172)$ \\
\hline TTPAL & TRIP6 & Upregulation & Promotes CRC tumorigenesis and predicts the shortened survival & $(173)$ \\
\hline NGX6 & TCF/LEF & Downregulation & $\begin{array}{l}\text { Inhibits CRC proliferation, invasion and metastasis, and promotes } \\
\text { CRC apoptosis }\end{array}$ & $(169)$ \\
\hline ISG15 & $\begin{array}{l}\text { Glycoprotein } \\
90 \mathrm{~K}\end{array}$ & Downregulation & $\begin{array}{l}\text { Promotes the degradation of } \beta \text {-catenin and subsequently inhibits } \\
\text { CRC progression }\end{array}$ & $(170)$ \\
\hline $\operatorname{Prdx} 2$ & GSK-3 $\beta$ & Upregulation & $\begin{array}{l}\text { Promotes CRC growth and the translocation of } \beta \text {-catenin in the } \\
\text { nucleus, and decreases the level of phospho- } \beta \text {-catenin }\end{array}$ & $(166)$ \\
\hline HMGA1 & TCF4 & Upregulation & $\begin{array}{l}\text { Promotes the formation of the } \beta \text {-catenin/TCF } 4 \text { complex, CRC cell } \\
\text { proliferation, and tumorigenesis }\end{array}$ & $(105)$ \\
\hline LGR5 & - & - & $\begin{array}{l}\text { Promotes CRC cell growth byinhibiting mitochondria-mediated } \\
\text { apoptosis }\end{array}$ & $(21)$ \\
\hline LHX4 & TCF4 & Upregulation & Promotes CRC cell proliferation & $(160)$ \\
\hline USP22 & $\operatorname{miR}-30-5 p$ & - & Promotes CRC chemoresistance and stemness & $(174,175)$ \\
\hline CAPN4 & MAPK7 & - & Promotes CRC cell proliferation & $(161)$ \\
\hline USP39 & - & Upregulation & $\begin{array}{l}\text { Induces CRC growth and metastasis bypromoting the expression of } \\
\text { TCF4, } \beta \text {-catenin, MMP- } 2 \text { and MMP-9 }\end{array}$ & $(60)$ \\
\hline USP44 & Axin 1 & - & Inhibits CRC proliferation and promotes apoptosis & $(176)$ \\
\hline RNF146 & Axin 1 & Upregulation & Promotes CRC cell growth and inhibits the apoptosis & $(162)$ \\
\hline E2A & FoxM1 & - & $\begin{array}{l}\text { Inhibits tumor-initiating capacity of CRC cells, CRC tumor } \\
\text { formation, and CRC liver metastasis }\end{array}$ & $(52)$ \\
\hline IFIT2 & IRF1 & Downregulation & $\begin{array}{l}\text { Confers apoptotic properties to CRC cells by caspase-mediated } \\
\text { activation }\end{array}$ & $(177,178)$ \\
\hline ACBP & LRP6 & - & $\begin{array}{l}\text { Inhibits CRC cell proliferation and phosphorylation of LRP6, and } \\
\text { promotes phosphorylation of } \beta \text {-catenin }\end{array}$ & $(171)$ \\
\hline RNF43 & DVL & - & Promotes the degradation of FZD and LRP6 via the fusion of DVL & $(167,168)$ \\
\hline ZNRF3 & DVL & - & Promotes the degradation of FZD and LRP6 via the fusion of DVL & $(167,168)$ \\
\hline \multicolumn{5}{|c|}{$\begin{array}{l}\text { NPTX2, neuronal pentraxin 2; EGFL6, epidermal growth factor-like protein } 6 \text {; (P)RR, (Pro)renin receptor; SLP-2, stomatin-like protein-2 } \\
\text { NUP153, nucleoporin 153; SATB1, special at-rich sequence-binding protein 1; TTPAL, alpha-tocopherol transfer protein-like; TRIP6 } \\
\text { thyroid receptor-interacting protein 6; NGX6, nasopharyngeal carcinoma associated gene 6; ISG15, interferon-stimulated gene-15; Prdx2 } \\
\text { peroxiredoxin 2; HMGA1, high mobility group A1; Lgr5, leucine-rich repeat-containing g protein-coupled receptor 5; LHX4, LIM homeobox } 4 \\
\text { USP22/39/44, ubiquitin-specific peptidase 22/39/44; CAPN4, calpain small subunit } 1 \text {; MAPK7, mitogen-activated protein kinase 7; RNF146 } \\
\text { E3 ubiquitin ligase ring finger protein 146; FoxM1, Forkhead box M1; IFIT2, interferon-induced proteins with tetratricopeptide repeats } 2 \\
\text { IRF1, interferon regulatory factor } 1 \text {; ACBP, anticancer bioactive peptide; RNF43, ring finger protein 43; ZNRF3, transmembrane E3 ubiquitin } \\
\text { ligase zinc and ring finger 3; MMP, matrix metalloproteinase. }\end{array}$} \\
\hline
\end{tabular}

pathway can be effectively targeted for CRC therapy. Additionally, the important clinical implications of targeting Wnt/ $\beta$-catenin signaling have been recognized for decades following the discovery of this pathway. Nevertheless, it has not been translated into the clinic. Three factors have hindered the development in this field: i) The complexity of the Wnt $/ \beta$-catenin signaling pathway is the main reason. There are 19 Wnt ligands in humans, which indicates the complexity of Wnt/ $\beta$-catenin signaling and biological functions, and knowledge of their roles in CRC tumorigenesis remains limited. The 
complexity of Wnt receptors parallels the complexity observed in the diversity of Wnt ligands. Wnt receptors mainly contain FZD family, LRP-5/6 and receptor tyrosine kinase-like orphan receptor-1/2. Its complexity is also reflected in the number of components involved in this pathway, including $\beta$-catenin, Axin, APC, GSK-3 $\beta$, DVL, CK1 and the TCF/LEF family. ii) The activity levels of the Wnt/ $\beta$-catenin signaling pathway differentially affect the regulatory functions of components in this pathway. For example, moderate activity levels of this pathway induce $\mathrm{CRC}$ proliferation and carcinogenesis, whereas relatively high levels lead to decreased CRC proliferation and increased apoptosis. Therefore, it is difficult to accurately know at which activity level of this pathway Wnt/ $\beta$-catenin signaling is effectively inhibited. iii) Approximately $90 \%$ of sporadic CRC cases harbor mutations in components of the Wnt/ $\beta$-catenin signaling pathway, such as APC, $\beta$-catenin, Axin1, Axin2 and TCF-4. Certain mutations are strongly associated with this pathway and contribute to constitutively active $\beta$-catenin, which is difficult to inhibit by antagonists of the upstream proteins of this pathway (15).

Collectively, these are the main challenges related to finding the optimaltherapeutic strategy and developing effective therapeutic agents via targeting the Wnt/ $\beta$-catenin signaling pathway in CRC.

\section{Conclusions and future perspectives}

In the present review, Wnt/ $\beta$-catenin-associated therapy targets for CRC have been described, and it has been revealed that they act as positive or negative regulators and play a pivotal role in therapeutic strategies against CRC. The carcinogenic effects of positive regulators are achieved by aberrantly activating the following pathway: Wnt $\rightarrow$ FZD $\rightarrow$ LRP5/6 $\rightarrow$ DVL $\rightarrow$ disassembly of $\beta$-catenin destruction complex $\rightarrow$ aberrant accumulation of $\beta$-catenin $\rightarrow$ nuclear translocation of $\beta$-catenin $\rightarrow \mathrm{TCF} / \mathrm{LEF} \rightarrow$ transcription of Wnt downstream target genes. Whereas, the anticarcinogenic effects of the negative regulators are achieved by inactivating this pathway. In these regulatory networks, once one of the components is abnormally expressed, a chain reaction ultimately affects the functions of targets for CRC in the Wnt/ $\beta$-catenin signaling pathway.

Despite numerous years of research on the canonical Wnt/ß-catenin signaling pathway, the underlying mechanism of how the activation of the extracellular Wnt signal leads to aberrant accumulation of intracellular $\beta$-catenin remains controversial. Therefore, further studies regarding this pathway in CRC are required, with focus on the following: i) Given the inhibitory effects of Traditional Chinese medicine on CRC, the strategy of integrated Chinese-Western medicine for CRC may be more effective. ii) Synergistic effects of multitarget therapy for cancers have been demonstrated. CRC heterogeneity may render targeted therapies ineffective. Therefore, certain multitarget therapeuticstrategies concurrently targeting Wnt/ $\beta$-catenin signaling should improve treatment. iii) Due to the complexity of Wnt $/ \beta$-catenin signaling, focus should be on further understanding the crosstalk among oncogenes. iv) More research will be required to identify the highly selective inhibitor for CRC to avoid unnecessary side effects. v) Identifying more inhibitors for downstream targets of the Wnt/ $\beta$-catenin signaling pathway may be a promising therapeutic strategy for CRC.

In the Wnt/ $\beta$-catenin signaling pathway, the roles of therapeutic targets for CRC have been previously established. However, these extensive studies suggest that the regulation of Wnt/ $\beta$-catenin signaling is more complex than previously hypothesized, and thus various mechanisms still need to be further elucidated. Further insight into these underlying mechanisms may enable deeper understanding of CRC tumorigenesis and metastasis, and identify novel diagnostic and prognostic markers, as well as potential therapeutic targets.

\section{Acknowledgements}

Not applicable.

\section{Funding}

The present review was supported by the Taizhou Science and Technology Support Plan (Social Development, guidance plan) project (grant nos. SSF20180130 and SSF20190011).

\section{Availability of data and materials}

Not applicable.

\section{Authors' contributions}

YJ and YH conceived and wrote the manuscript. JL was involved in collecting the references and reviewing the manuscript. DS critically revised the manuscript. Data authentication is not applicable. All authors read and approved the final manuscript.

\section{Ethics approval and consent to participate}

Not applicable.

\section{Patient consent for publication}

Not applicable.

\section{Competing interests}

The authors declare that they have no competing interests.

\section{References}

1. Tao L, Zhu Y, Gu Y, Zheng J and Yang J: ARHGAP25: A negative regulator of colorectal cancer (CRC) metastasis via the Wnt/beta-catenin pathway. Eur J Pharmacol 858: 172476, 2019.

2. Sun X, Xu X and Song L: TKP, a serine protease extracted from Trichosanthes kirilowii, inhibits the migration and invasion of colorectal adenocarcinoma cells by targeting Wnt/ $\beta$-catenin and Hedgehog/Gli1 signalings. Phytother Res 34: 867-878, 2020.

3. Xu C, Tian G, Jiang C, Xue H, Kuerbanjiang M, Sun L, Gu L, Zhou H, Liu Y, Zhang Z and Xu Q: NPTX2 promotes colorectal cancer growth and liver metastasis by the activation of the canonical Wnt/ $\beta$-catenin pathway via FZD6. Cell Death Dis 10: 217, 2019.

4. Wang J, Shibayama Y, Zhang A, Ohsaki H, Asano E, Suzuki Y, Kushida Y, Kobara H, Masaki T, Wang Z and Nishiyama A: (Pro)renin receptor promotes colorectal cancer through the Wnt/beta-catenin signaling pathway despite constitutive pathway component mutations. Br J Cancer 120: 229-237, 2019. 
5. Wang W, He Y, Rui J and Xu MQ: MiR-410 acts as an oncogene in colorectal cancer cells by targeting dickkopf-related protein 1 via the Wnt/ $\beta$-catenin signaling pathway. Oncol Lett 17: 807-814, 2019.

6. Tang Q, Chen J, Di Z, Yuan W, Zhou Z, Liu Z, Han S, Liu Y, Ying $G$, Shu $X$ and Di M: TM4SF1 promotes EMT and cancer stemness via the $\mathrm{Wnt} / \beta$-catenin/SOX2 pathway in colorectal cancer. J Exp Clin Cancer Res 39: 232, 2020.

7. Lu ML, Zhang Y, Li J, Fu Y, Li WH, Zhao GF, Li XH, Wei L, Liu GB and Huang H: MicroRNA-124 inhibits colorectal cancer cell proliferation and suppresses tumor growth by interacting with PLCB1 and regulating Wnt $/ \beta$-catenin signaling pathway. Eur Rev Med Pharmacol Sci 23: 121-136, 2019.

8. Shan Z, An N, Qin J, Yang J, Sun H and Yang W: Long non-coding RNA Linc00675 suppresses cell proliferation and metastasis in colorectal cancer via acting on miR-942 and Wnt/ $\beta$-catenin signaling. Biomed Pharmacother 101: 769-776, 2018.

9. Bian J, Dannappel M, Wan C and Firestein R: Transcriptional regulation of $\mathrm{Wnt} / \beta$-catenin pathway in colorectal cancer. Cells 9: 2125, 2020.

10. Yuan S, Tao F, Zhang X, Zhang Y, Sun X and Wu D: Role of $\mathrm{Wnt} / \beta$-catenin signaling in the chemoresistance modulation of colorectal cancer. Biomed Res Int 2020: 9390878, 2020.

11. Amado NG, Predes D, Moreno MM, Carvalho IO, Mendes FA and Abreu JG: Flavonoids and Wnt/ $\beta$-catenin signaling: Potential role in colorectal cancer therapies. Int J Mol Sci 15: 12094-12106, 2014.

12. Liang G, Fang X, Yang Y and Song Y: Silencing of CEMIP suppresses Wnt/ $\beta$-catenin/Snail signaling transduction and inhibits EMT program of colorectal cancer cells. Acta Histochem 20: 56-63, 2018.

13. Yang E, Tacchelly-Benites O, Wang Z, Randall MP, Tian A, Benchabane H, Freemantle S, Pikielny C, Tolwinski NS, Lee E and Ahmed Y: Wnt pathway activation by ADP-ribosylation. Nat Commun 7: 11430, 2016.

14. Rennoll S and Yochum G: Regulation of MYC gene expression by aberrant Wnt/ $\beta$-catenin signaling in colorectal cancer. World J Biol Chem 6: 290-300, 2015.

15. Cheng X, Xu X, Chen D, Zhao F and Wang W: Therapeutic potential of targeting the $\mathrm{Wnt} / \beta$-catenin signaling pathway in colorectal cancer. Biomed Pharmacother 110: 473-481, 2019.

16. Schuijers J, Mokry M, Hatzis P, Cuppen E and Clevers H: Wnt-induced transcriptional activation is exclusively mediated by TCF/LEF. EMBO J 33: 146-156, 2014.

17. Wang S, Yang H, Chen X and Jiang Z: Effects of SOX15 on the colorectal cancer cells via downregulation of the Wnt/ $\beta$-catenin signaling pathway. Future Oncol 14: 1921-1932, 2018.

18. Bernkopf DB, Daum G, Brückner M and Behrens J: Sulforaphane inhibits growth and blocks Wnt/ $\beta$-catenin signaling of colorectal cancer cells. Oncotarget 9: 33982-33994, 2018.

19. Murad LB, da Silva Nogueira P, de Araújo WM, Sousa-Squiavinato ACM, Rocha MR, de Souza WF de-Freitas-Junior J, Barcellos-de-Souza P, Bastos LG and Morgado-Díaz JA: Docosahexaenoic acid promotes cell cycle arrest and decreases proliferation through $\mathrm{WNT} / \beta$-catenin modulation in colorectal cancer cells exposed to Y-radiation. Biofactors 45: 24-34, 2019.

20. Escudero-Paniagua B,Bartolomé RA, Rodríguez S, De Los Ríos V, Pintado L, Jaén M, Lafarga M, Fernández-Aceñero MJ and Casal JI: PAUF/ZG16B promotes colorectal cancer progression through alterations of the mitotic functions and the Wnt/ $\beta$-catenin pathway. Carcinogenesis 41: 203-213, 2020.

21. Hsu HC, Liu YS, Tseng KC, Tan BC, Chen SJ and Chen HC: LGR5 regulates survival through mitochondria-mediated apoptosis and by targeting the Wnt/ $\beta$-catenin signaling pathway in colorectal cancer cells. Cell Signal 26: 2333-2342, 2014.

22. He TC, Sparks AB, Rago C, Hermeking H, Zawel L, Da Costa LT, Morin PJ, Vogelstein B and Kinzler KW: Identification of c-MYC as a target of the APC pathway. Science 281: 1509-1512, 1998.

23. Tetsu O and McCormick F: Beta-catenin regulates expression of cyclin D1 in coloncarcinoma cells. Nature 398: 422-426, 1999.

24. Brabletz T, Jung A, Dag S, Hlubek F and Kirchner T: Beta-catenin regulates the expression of the matrix metalloproteinase-7 in human colorectal cancer. Am J Pathol 155: 1033-1038, 1999.

25. Zhang X, Xiong Y, Tang F, Bian Y, Chen Y and Zhang F: Long noncoding RNA HNF1A-AS1 indicates a poor prognosis of colorectal cancer and promotes carcinogenesis via activation of the Wnt/ $\beta$-catenin signaling pathway. Biomed Pharmacother 96: $877-883,2017$
26. Baldus SE, Monig SP, Huxel S, Landsberg S, Hanisch FG, Engelmann K, Schneider PM, Thiele J, Holscher AH and Dienes HP: MUC1 and nuclear beta-catenin are coexpressed at the invasion front of colorectal carcinomas and are both correlated with tumor prognosis. Clin Cancer Res 10: 2790-2796, 2004.

27. Bordonaro $\mathrm{M}$ and Lazarova DL: CREB-binding protein p300, butyrate, and Wnt signaling in colorectal cancer. World J Gastroenterol 21: 8238-8248, 2015 .

28. Lazarova DL, Chiaro C, Wong T, Drago E, Rainey A, O'Malley S and Bordonaro M: CBP activity mediates effects of the histone deacetylase inhibitor butyrate on WNT activity and apoptosis in colon cancer cells. J Cancer 4: 481-490, 2013.

29. Giles RH, van Es JH and Clevers H: Caught up in a Wnt storm: Wnt signaling in cancer. Biochim Biophys Acta 1653: 1-24, 2003.

30. Farkas SA, Vymetalkova V, Vodickova L, Vodicka P and Nilsson TK: DNA methylation changes in genes frequently mutated in sporadic colorectal cancer and in the DNA repair and Wnt/ $\beta$-catenin signaling pathway genes. Epigenomics 6: 179-191, 2014.

31. Yang D, Li Q, Shang R, Yao L, Wu L, Zhang M, Zhang L, Xu M, Lu Z, Zhou J, et al: WNT4 secreted by tumor tissues promotes tumor progression in colorectal cancer by activation of the Wnt/ $\beta$-catenin signalling pathway. J Exp Clin Cancer Res 39: 251, 2020.

32. Prossomariti A, Piazzi G, Alquati C and Ricciardiello L: Are Wnt/ $\beta$-catenin and PI3K/AKT/mTORC1 distinct pathways in colorectal cancer? Cell Mol Gastroenterol Hepatol 10: 491-506, 2020

33. Li W, Yang CJ, Wang LQ, Wu J, Dai C, Yuan YM, Li GQ and Yao MC: A tannin compound from Sanguisorba officinalis blocks Wnt/ $\beta$-catenin signaling pathway and induces apoptosis of colorectal cancer cells. Chin Med 14: 22, 2019.

34. Duval A, Rolland S, Tubacher E, Bui H, Thomas G and Hamelin R: The human T-cell transcription factor-4 gene: Structure, extensive characterization of alternative splicings, and mutational analysis in colorectal cancer cell lines. Cancer Res 60: 3872-3879, 2000.

35. Wu Y, Fang G, Wang X, Wang H, Chen W, Li L, Ye T, Gong L, Ke C and Cai Y: NUP153 overexpression suppresses the proliferation of colorectal cancer by negatively regulating Wnt $/ \beta$-catenin signaling pathway and predicts good prognosis. Cancer Biomark 24: 61-70, 2019.

36. Tang Q, Zou Z, Zou C, Zhang Q, Huang R, Guan X, Li Q, Han Z, Wang D, Wei H, et al: MicroRNA-93 suppress colorectal cancer development via $\mathrm{Wnt} / \beta$-catenin pathway downregulating. Tumour Biol 36: 1701-1710, 2015.

37. Ye Q, Yao G, Zhang M, Guo G, Hu Y, Jiang J, Cheng L, Shi J, $\mathrm{Li} \mathrm{H}$, Zhang $\mathrm{Y}$ and Liu $\mathrm{H}$ : A novel ent-kaurane diterpenoid executes antitumor function in colorectal cancer cells by inhibiting Wnt/ $\beta$-catenin signaling. Carcinogenesis 36: 318-326, 2015.

38. Jin LH, Shao QJ, Luo W, Ye ZY, Li Q and Lin SC: Detection of point mutations of the Axin1 gene in colorectal cancers. Int J Cancer 107: 696-699, 2003

39. Humphries A and Wright NA: Colonic crypt organization and tumorigenesis. Nat Rev Cancer 8: 415-424, 2008.

40. Cancer Genome Atlas Network: Comprehensive molecular characterization of human colon and rectal cancer. Nature 487: 330-337, 2012

41. Chen HY, Lang YD, Lin HN, Liu YR, Liao CC, Nana AW, Yen Y and Chen RH: MiR-103/107 prolong Wnt/ $\beta$-catenin signaling and colorectal cancer stemness by targeting Axin2. Sci Rep 9: 9687, 2019

42. Sun Y, Lai X, Yu Y, Li J, Cao L, Lin W, Huang C, Liao J, Chen W, Li C, et al: Inhibitor of DNA binding 1 (Id1) mediates stemness of colorectal cancer cells through the Id1-c-Myc-PLAC8 axis via the Wnt/ $\beta$-catenin and Shh signaling pathways. Cancer Manag Res 11: 6855-6869, 2019.

43. Ayinde O, Wang Z, Pinton G, Moro L and Griffin M: Transglutaminase 2 maintains a colorectal cancer stem phenotype by regulating epithelial-mesenchymal transition. Oncotarget 10: 4556-4569, 2019.

44. Chen Y, Li Y, Wang XQ, Meng Y, Zhang Q, Zhu JY, Chen JQ, Cao WS, Wang XQ, Xie CF, et al: Phenethyl isothiocyanate inhibits colorectal cancer stem cells by suppressing Wnt/ $\beta$-catenin pathway. Phytother Res 32: 2447-2455, 2018.

45. Chi J, Zhang H, Hu J, Song Y, Li J, Wang L and Wang Z: AGR3 promotes the stemness of colorectal cancer via modulating Wnt// -catenin signalling. Cell Signal 65: 109419, 2020.

46. Wang P, Gao XY, Yang SQ, Sun ZX, Dian LL, Qasim M, Phyo AT, Liang ZS and Sun YF: Jatrorrhizine inhibits colorectal carcinoma proliferation and metastasis through Wnt/ $\beta$-catenin signaling pathway and epithelial-mesenchymal transition. Drug Des Devel Ther 13: 2235-2247, 2019. 
47. Cho YH, Ro EJ, Yoon JS, Mizutani T, Kang DW, Park JC, Il Kim T, Clevers $\mathrm{H}$ and Choi KY: 5-FU promotes stemness of colorectal cancer via p53-mediated $\mathrm{WNT} / \beta$-catenin pathway activation. Nat Commun 11: 5321, 2020.

48. Chen S, Song X, Chen Z, Li X, Li M, Liu H and Li J: CD133 expression and the prognosis of colorectal cancer: A systematic review and meta-analysis. PLoS One 8: e56380, 2013.

49. Zhang Q, Li XT, Chen Y, Chen JQ, Zhu JY, Meng Y, Wang XQ, Li Y, Geng SS, Xie CF, et al: Wnt/beta-catenin signaling mediates the suppressive effects of diallyl trisulfide on colorectal cancer stem cells. Cancer Chemother Pharmacol 81: 969-977, 2018.

50. Dahal Lamichane B, Jung SY, Yun J, Kang S, Kim DY, Lamichane S, Kim YJ, Park JH, Jang WB, Ji ST, et al: AGR2 is a target of canonical Wnt $/ \beta$-catenin signaling and is important for stemness maintenance in colorectal cancer stem cells. Biochem Biophys Res Commun 515: 600-606, 2019.

51. Yang AD, Fan F, Camp ER, ven Buren G, Liu W, Somcio R, Gray MJ, Cheng H, Hoff PM and Ellis LM: Chronic oxaliplatin resistance induces epithelial-to-mesenchymal transition in colorectal cancer cell lines. Clin Cancer Res 12 (14 Pt 1): 4147-4153, 2006

52. Zhao H, Zhao C, Li H, Zhang D and Liu G: E2A attenuates tumor-initiating capacity of colorectal cancer cells via the Wnt/beta-catenin pathway. J Exp Clin Cancer Res 38: 276, 2019.

53. Ma CT, Luo HS, Gao F, Tang QC and Chen W: Fusobacterium nucleatum promotes the progression of colorectal cancer by interacting with E-cadherin. Oncol Lett 16: 2606-2612, 2018.

54. Ghahhari NM and Babashah S: Interplay between microRNAs and WNT/ $\beta$-catenin signalling pathway regulates epithelial-mesenchymal transition in cancer. Eur J Cancer 51: 1638-1649, 2015.

55. Yuan Z, Yu X, Ni B, Chen D, Yang Z, Huang J, Wang J, Chen D and Wang L: Overexpression of long non-coding RNA-CTD903 inhibits colorectal cancer invasion and migration by repressing $\mathrm{Wnt} / \beta$-catenin signaling and predicts favorable prognosis. Int J Oncol 48: 2675-2685, 2016.

56. Qi J, Yu Y, Akilli Öztürk Ö, Holland JD, Besser D, Fritzmann J, Wulf-Goldenberg A, Eckert K, Fichtner I and Birchmeier W: New Wnt/ $\beta$-catenin target genes promote experimental metastasis and migration of colorectal cancer cells through different signals. Gut 65: 1690-1701, 2016.

57. Gu Y, Wang Q, Guo K, Qin W, Liao W, Wang S, Ding Y and Lin J: TUSC3 promotes colorectal cancer progression and epithelial-mesenchymal transition (EMT) through WNT/ $\beta$-catenin and MAPK signalling. J Pathol 239: 60-71, 2016.

58. Yuan H, Wei R, Xiao Y, Song Y, Wang J, Yu H, Fang T, Xu W and Mao S: RHBDF1 regulates APC-mediated stimulation of the epithelial-to-mesenchymal transition and proliferation of colorectal cancer cells in part via the $\mathrm{Wnt} / \beta$-catenin signalling pathway. Exp Cell Res 368: 24-36, 2018.

59. Ren Y, Tao J, Jiang Z, Guo D and Tang J: Pimozide suppresses colorectal cancer via inhibition of $\mathrm{Wnt} / \beta$-catenin signaling pathway. Life Sci 209: 267-273, 2018.

60. Yuan X, Sun X, Shi X, Wang H, Wu G, Jiang C, Yu D, Zhang W, Xue B and Ding Y: USP39 promotes colorectal cancer growth and metastasis through the $\mathrm{Wnt} / \beta$-catenin pathway. Oncol Rep 37: 2398-2404, 2017.

61. Slack FJ and Chinnaiyan AM: The role of Non-coding RNAs in oncology. Cell 179: 1033-1055, 2019.

62. Zhang Z, Zhou C, Chang Y,Zhang Z, Hu Y,Zhang F, Lu Y,Zheng L, Zhang W, Li X and Li X: Long non-coding RNA CASC11 interacts with hnRNP-K and activates the WNT/ $\beta$-catenin pathway to promote growth and metastasis in colorectal cancer. Cancer Lett 376: 62-73, 2016.

63. Ye Y, Gu B, Wang Y, Shen S and Huang W: YY1-induced upregulation of long noncoding RNA ARAP1-AS1 promotes cell migration and invasion in colorectal cancer through the Wnt/ $\beta$-catenin signaling pathway. Cancer Biother Radiopharm 34: 519-528, 2019.

64. Liao T, Maierdan SL and Lv C: ROR1-AS1 promotes tumorigenesis of colorectal cancer via targeting Wnt/ $\beta$-catenin. Eur Rev Med Pharmacol Sci 24: 7561, 2020.

65. Wang X, Zhou J, Xu M, Yan Y, Huang L, Kuang Y, Liu Y, Li P, Zheng W, Liu H and Jia B: A 15-lncRNA signature predicts survival and functions as a ceRNA in patients with colorectal cancer. Cancer Manag. Res 10: 5799-5806, 2018

66. Li S, Wu T, Zhang D, Sun X and Zhang X: The long non-coding RNA HCG18 promotes the growth and invasion of colorectal cancer cells through sponging miR-1271 and upregulating MTDH/Wnt/ $\beta$-catenin. Clin Exp Pharmacol Physiol 47: 703-712, 2020.
67. Sun LB, Zhao SF, Zhu JJ, Han Y and Shan TD: Long noncoding RNA UCID sponges miR-152-3p to promote colorectal cancer cell migration and invasion via the $\mathrm{Wnt} / \beta$-catenin signaling pathway. Oncol Rep 44: 1194-1205, 2020.

68. Jin YD, Ren YR, Gao YX, Zhang L and Ding Z: Hsa circ_0005075 predicts a poor prognosis and acts as an oncogene in colorectal cancer via activating Wnt/ $\beta$-catenin pathway. Eur Rev Med Pharmacol Sci 23: 3311-3319, 2019.

69. Chen B, Zhang D, Kuai J, Cheng M, Fang X and Li G: Upregulation of miR-199a/b contributes to cisplatin resistance via Wnt/ $\beta$-catenin-ABCG2 signaling pathway in ALDHA $1^{+}$colorectal cancer stem cells. Tumour Biol 39: 1010428317715155, 2017.

70. Wan YC, Li T, Han YD, Zhang HY, Lin H and Zhang B: MicroRNA-155 enhances the activation of Wnt/ $\beta$-catenin signaling in colorectal carcinoma by suppressing HMG-box transcription factor 1. Mol Med Rep 13: 2221-2228, 2016.

71. Li Q, Lai Q, He C, Fang Y, Yan Q, Zhang Y, Wang X, Gu C, Wang Y, Ye L, et al: RUNX1 promotes tumour metastasis by activating the $\mathrm{Wnt} / \beta$-catenin signaling pathway and EMT in colorectal cancer. J Exp Clin Cancer Res 38: 334, 2019.

72. Li J, He M, Xu W and Huang S: LINC01354 interacting with hnRNP-D contributes to the proliferation and metastasis in colorectal cancer through activating Wnt $/ \beta$-catenin signaling pathway. J Exp Clin Cancer Res 38: 161, 2019.

73. Qi H, Wang J, Wang F and Ma H: Long non-coding RNA SNHG1 promotes cell proliferation and tumorigenesis in colorectal cancer via Wnt/ $\beta$-catenin signaling. Pharmazie 72: 395-401, 2017.

74. Liu R, Deng P, Zhang Y, Wang Y and Peng C: Circ 0082182 promotes oncogenesis and metastasis of colorectal cancer in vitro and in vivo by sponging miR-411 and miR-1205 to activate the Wnt/ $\beta$-catenin pathway. World J Surg Oncol 19: 51, 2021.

75. Fang Q, Yang A, Dong A and Zhao L: circPDSS1 stimulates the development of colorectal cancer via activating the Wnt/ $\beta$-catenin signaling. Onco Targets Ther 13: 6329-6337, 2020.

76. Zheng K, Zhou X, Yu J, Li Q, Wang H, Li M, Shao Z, Zhang F, Luo Y, Shen Z, et al: Epigenetic silencing of miR-490-3p promotes development of an aggressive colorectal cancer phenotype through activation of the Wnt/ $/$-catenin signaling pathway. Cancer Lett 376: 178-187, 2016

77. Gu C, Cai J, Xu Z, Zhou S, Ye L, Yan Q, Zhang Y, Fang Y, Liu Y, Tu C, et al: MiR-532-3p suppresses colorectal cancer progression by disrupting the ETS1/TGM2 axis-mediated Wnt/ $\beta$-catenin signaling. Cell Death Dis 10: 739, 2019.

78. Yu FB, Sheng J, Yu JM, Liu JH, Qin XX and Mou B: MiR-19a-3p regulates the Forkhead box F2-mediated Wnt $/ \beta$-catenin signaling pathway and affects the biological functions of colorectal cancer cells. World J Gastroenterol 26: 627-644, 2020.

79. Wu J, Chen Z, Liu W, Zhang Y, Feng W, Yuan Y, Ye J, Wang L, Cai S, He Y, et al: MicroRNA-188-5p targeting Forkhead Box L1 promotes colorectal cancer progression via activating $\mathrm{Wnt} / \beta$-catenin signaling. Oncol Res: Nov 23, 2020 (Epub ahead of print).

80. Huang L, Liu Z, Hu J, Luo Z, Zhang C, Wang L and Wang Z: MiR-377-3p suppresses colorectal cancer through negative regulation on Wnt/ $\beta$-catenin signaling by targeting XIAP and ZEB2. Pharmacol Res 156: 104774, 2020.

81. Sun N, Zhang L, Zhang C and Yuan Y: MiR-144-3p inhibits cell proliferation of colorectal cancer cells by targeting BCL6 via inhibition of Wnt/ $\beta$-catenin signaling. Cell Mol Biol Lett 25: 19, 2020.

82. Luo Y, Chen JJ, Lv Q, Qin J, Huang YZ, Yu MH and Zhong M: Long non-coding RNA NEAT1 promotes colorectal cancer progression by competitively binding miR-34a with SIRT1 and enhancing the Wnt/ $\beta$-catenin signaling pathway. Cancer Lett 441: 11-22, 2019.

83. Wang G, Li Z, Zhao Q, Zhu Y, Zhao C, Li X, Ma Z, Li X and Zhang Y: LincRNA-p21 enhances the sensitivity of radiotherapy for human colorectal cancer by targeting the Wnt/ $\beta$-catenin signaling pathway. Oncol Rep 31: 1839-1845, 2014.

84. Ma Y, Yang Y, Wang F, Moyer MP, Wei Q, Zhang P, Yang Z, Liu W, Zhang $\mathrm{H}$, Chen $\mathrm{N}$, et al: Long non-coding RNA CCAL regulates colorectal cancer progression by activating $\mathrm{Wnt} / \beta$-catenin signaling pathway via suppression of activator protein $2 \alpha$. Gut 65: 1494-1504, 2016.

85. Wu KF, Liang WC, Feng L, Pang JX, Waye MM, Zhang JF and Fu WM: H19 mediates methotrexate resistance in colorectal cancer through activating Wnt/ $\beta$-catenin pathway. Exp Cell Res 350: 312-317, 2017.

86. Zhou T, Wu L, Ma N, Tang F, Zong Z and Chen S: LncRNA PART1 regulates colorectal cancer via targeting $\mathrm{miR}-150-5 \mathrm{p} / \mathrm{miR}-520 \mathrm{~h} / \mathrm{CTNNB} 1$ and activating Wnt $/ \beta$-catenin pathway. Int J Biochem Cell Biol 118: 105637, 2020. 
87. Song J, Shu H, Zhang L and Xiong J: Long noncoding RNA GAS5 inhibits angiogenesis and metastasis of colorectal cancer through the Wnt/ $\beta$-catenin signaling pathway. J Cell Biochem: Jan 22, 2019 (Epub ahead of print).

88. Zhu Y, Bian Y, Zhang Q, Hu J, Li L, Yang M, Qian H, Yu L, Liu B and Qian X: LINC00365 promotes colorectal cancer cell progression through the $\mathrm{Wnt} / \beta$-catenin signaling pathway. J Cell Biochem 121: 1260-1272, 2020.

89. Liu Z, Gu Y, Cheng X, Jiang H, Huang Y, Zhang Y, Yu G, Cheng Y and Zhou L: Upregulation lnc-NEAT1 contributes to colorectal cancer progression through sponging miR-486-5p and activating NR4A1/Wnt/ $\beta$-catenin pathway. Cancer Biomark 30: 309-319, 2021.

90. Duan W, Kong X, Li J, Li P, Zhao Y, Liu T, Binang HB, Wang Y, Du L and Wang C: LncRNA AC010789.1 promotes colorecta cancer progression by targeting MicroRNA-432-3p/ZEB1 axis and the Wnt/ $\beta$-catenin signaling pathway. Front Cell Dev Biol 8: 565355,2020

91. Tang X, Sun G, He Q, Wang C, Shi J, Gao L, Ye J, Liang Y and $\mathrm{Qu} \mathrm{H}$ : Circular noncoding RNA circMBOAT2 is a novel tumor marker and regulates proliferation/migration by sponging miR-519d-3p in colorectal cancer. Cell Death Dis 11: 625, 2020

92. Chen H, Pei L, Xie P and Guo G: Circ-PRKDC contributes to 5 -Fluorouracil resistance of colorectal cancer cells by regulating miR-375/FOXM1 Axis and Wnt/ק-catenin pathway. Onco Targets Ther 13: 5939-5953, 2020.

93. Fang G, Ye BL, Hu BR, Ruan XJ and Shi YX: CircRNA_100290 promotes colorectal cancer progression through miR-516b-induced downregulation of FZD4 expression and Wnt/ $\beta$-catenin signaling. Biochem Biophys Res Commun 504: 184-189, 2018.

94. Ge Z, Li LF, Wang CY, Wang Y and Ma WL: CircMTO1 inhibits cell proliferation and invasion by regulating Wnt/ $\beta$-catenin signaling pathway in colorectal cancer. Eur Rev Med Pharmacol Sci 22: 8203-8209, 2018

95. Li JW, Huang CZ, Li JH, Yuan JH, Chen QH, Zhang WF, Xu ZS, Liu YP, Li Y, Zhan MX and Lu LG: Knockdown of metadherin inhibits cell proliferation and migration in colorectal cancer. Oncol Rep 40: 2215-2223, 2018.

96. Huang G, Wu X, Li S, Xu X, Zhu H and Chen X: The long noncoding RNA CASC2 functions as a competing endogenous RNA by sponging miR-18a in colorectal cancer. Sci Rep 6: 26524,2016

97. Zeng K, Chen X, Xu M, Liu X, Hu X, Xu T, Sun H, Pan Y, He B and Wang S: CircHIPK3 promotes colorectal cancer growth and metastasis by sponging miR-7. Cell Death Dis 9: 417,2018.

98. Pálmer HG, González-Sancho JM, Espada J, Berciano MT, Puig I, Baulida J, Quintanilla M, Cano A, de Herreros AG, Lafarga $M$ and Muñoz A: Vitamin D(3) promotes the differentiation of colon carcinoma cells by the induction of E-cadherin and the inhibition of beta-catenin signaling. J Cell Biol 154: 369-387, 2001

99. Sadot E, Simcha I, Shtuman M, Ben-Ze'ev A and Geiger B: Inhibition of beta-catenin-mediated transactivation by cadherin derivatives. Proc Natl Acad Sci USA 95: 15339-15344, 1998.

100. Orsulic S, Huber O, Aberle H, Arnold S and Kemler R: E-cadherin binding prevents beta-catenin nuclear localization and beta-catenin/LEF-1-mediated transactivation. J Cell Sci 112 (Pt 8): 1237-1245, 1999.

101. Shahi S, Ang CS and Mathivanan S: A high-resolution mass spectrometry-based quantitative metabolomic workflow highlights defects in 5-fluorouracil metabolism in cancer cells with acquired chemoresistance. Biology (Basel) 9: 96, 2020.

102. Urushibara S, Tsubota T, Asai R, Azumi J, Ashida K, Fujiwara Y and Shiota G: WNT/ $\beta$-Catenin Signaling Inhibitor IC-2 Suppresses Sphere Formation and Sensitizes Colorectal Cancer Cells to 5-Fluorouracil. Anticancer Res 37: 4085-4091, 2017.

103. Emami KH, Nguyen C, Ma H, Kim DH, Jeong KW, Eguchi M, Moon RT, Teo JL, Kim HY, Moon SH, et al: A small molecule inhibitor of beta-catenin/CREB-binding protein transcription [corrected]. Proc Natl Acad Sci USA 101: 12682-12687, 2004

104. Ma H, Nguyen C, Lee KS and Kahn M: Differential roles for the coactivators $\mathrm{CBP}$ and $\mathrm{p} 300$ on TCF/beta-catenin-mediated survivin gene expression. Oncogene 24: 3619-3631, 2005.

105. Xing J, Cao G and Fu C: HMGA1 interacts with $\beta$-catenin to positively regulate $\mathrm{Wnt} / \beta$-catenin signaling in colorectal cancer cells. Pathol Oncol Res 20: 847-851, 2014.

106. Tian S, Hu J, Tao K, Wang J, Chu Y, Li J, Liu Z, Ding X, Xu L, Li Q, et al: Secreted AGR2 promotes invasion of colorectal cancer cells via Wnt 11-mediated non-canonical Wnt signaling. Exp Cell Res 364: 198-207, 2018
107. Zhao ZR, Zhang ZY, Zhang H, Jiang L, Wang MW and Sun XF: Overexpression of Id-1 protein is a marker in colorectal cancer progression. Oncol Rep 19: 419-424, 2008.

108. Cheng H, Sun X, Li J, He P, Liu W and Meng X: Knockdown of Uba2 inhibits colorectal cancer cell invasion and migration through downregulation of the Wnt/beta-catenin signaling pathway. J Cell Biochem 119: 6914-6925, 2018.

109. Hu TH, Yao Y, Yu S, Han LL, Wang WJ, Guo H, Tian T, Ruan ZP, Kang XM, Wang J, et al: SDF-1/CXCR4 promotes epithelial-mesenchymal transition and progression of colorectal cancer by activation of the $\mathrm{Wnt} / \beta$-catenin signaling pathway. Cancer Lett 354: 417-426, 2014.

110. Yang Y, Zhao Y, Hu N, Zhao J and Bai Y: lncRNA KIAA0125 functions as a tumor suppressor modulating growth and metastasis of colorectal cancer via Wnt/ $\beta$-catenin pathway. Cell Biol Int 43: 1463-1470, 2019

111. Matsuo J, Haga S, Hashimoto K, Okubo T, Ozawa T, Ozaki $\mathrm{M}$ and Yamaguchi $\mathrm{H}$ : Activation of caspase-3 during Chlamydia trachomatis-induced apoptosis at a late stage. Can J Microbiol 65: 135-143, 2019.

112. Lenz HJ and Kahn M: Safely targeting cancer stem cells via selective catenin coactivator antagonism. Cancer Sci 105: 1087-1092, 2014.

113. Hague A, Elder DJ, Hicks DJ and Paraskeva C: Apoptosis in colorectal tumour cells: Induction by the short chain fatty acids butyrate, propionate and acetate and by the bile salt deoxycholate. Int J Cancer 60: 400-406, 1995.

114. Bingham SA, Day NE, Luben R, Ferrari P, Slimani N, Norat T, Clavel-Chapelon F, Kesse E, Nieters A, Boeing H, et al: Dietary fibre in food and protection against colorectal cancer in the European prospective investigation into cancer and nutrition (EPIC): An observational study. Lancet 361: 1496-1501, 2003.

115. Lazarova DL, Bordonaro M, Carbone R and Sartorelli AC Linear relationship between Wnt activity levels and apoptosis in colorectal carcinoma cells exposed to butyrate. Int J Cancer 110: 523-531, 2004

116. Lazarova DL, Wong T, Chiaro C, Drago E and Bordonaro M: p300 influences butyrate-mediated WNT hyperactivation in colorectal cancer cells. J Cancer 4: 491-501, 2013.

117. Lazarova D, Lee A, Wong T, Marian B, Chiaro C, Rainey C and Bordonaro M: Modulation of Wnt activity and cell physiology by butyrate in lt97 microadenoma cells. J Cancer 5: 203-213, 2014.

118. Medina V, Edmonds B, Young GP, James R, Appleton S and Zalewski PD: Induction of caspase-3 protease activity and apoptosis by butyrate and trichostatin A (inhibitors of histone deacetylase): Dependence on protein synthesis and synergy with a mitochondrial/cytochrome c-dependent pathway. Cancer Res 57: 3697-3707, 1997.

119. Bordonaro M, Lazarova DL and Sartorelli AC: The activation of beta-catenin by Wnt signaling mediates the effects of histone deacetylase inhibitors. Exp Cell Res 313: 1652-1666, 2007.

120. Yang P, Yu D, Zhou J, Zhuang S and Jiang T: TGM2 interference regulates the angiogenesis and apoptosis of colorectal cancer via Wnt $/ \beta$-catenin pathway. Cell Cycle 18: 1122-1134, 2019.

121. Azevedo Martins JM, Rabelo-Santos SH, do Amaral Westin MC and Zeferino LC: Tumoral and stromal expression of MMP-2, MMP-9, MMP-14, TIMP-1, TIMP-2, and VEGF-A in cervical cancer patient survival: A competing risk analysis. BMC Cancer 20: 660, 2020.

122. Surh YJ: Cancer chemoprevention with dietary phytochemicals. Nat Rev Cancer 3: 768-780, 2003.

123. Amado NG, Fonseca BF, Cerqueira DM, Reis AH, Simas AB, Kuster RM, Mendes FA and Abreu JG: Effects of natural compounds on xenopus embryogenesis: A potential read out for functional drug discovery targeting $\mathrm{Wnt} / \beta$-catenin signaling. Curr Top Med Chem 12: 2103-2113, 2012.

124. Sun H, Jiang C, Cong L, Wu N, Wang X, Hao M, Liu T, Wang L, Liu Y and Cong X: CYP24A1 inhibition facilitates the antiproliferative effect of $1,25(\mathrm{OH})_{2} \mathrm{D}_{3}$ through downregulation of the WNT/ $\beta$-catenin pathway and methylation-mediated regulation of CYP24A1 in colorectal cancer cells. DNA Cell Biol 37: 742-749, 2018

125. Park CH, Chang JY, Hahm ER, Park S, Kim HK and Yang CH: Quercetin, a potent inhibitor against beta-catenin/Tcf signaling in SW480 colon cancer cells. Biochem Biophys Res Commun 328: 227-234, 2005

126. Pahlke G, Ngiewih Y, Kern M, Jakobs S, Marko D and Eisenbrand G: Impact of quercetin and EGCG on key elements of the Wnt pathway in human colon carcinoma cells. J Agric Food Chem 54: 7075-7082, 2006 
127. Ju J, Hong J, Zhou JN, Pan Z, Bose M, Liao J, Yang GY, Liu YY, Hou Z, Lin Y, et al: Inhibition of intestinal tumorigenesis in Apcmin/+ mice by (-)-epigallocatechin-3-gallate, the major catechin in green tea. Cancer Res 65: 10623-10631, 2005.

128. Bose M, Hao X, Ju J, Husain A, Park S, Lambert JD and Yang CS: Inhibition of tumorigenesis in ApcMin/+ mice by a combination of (-)-epigallocatechin-3-gallate and fish oil J Agric Food Chem 55: 7695-7700, 2007.

129. Kaur M, Velmurugan B, Tyagi A, Agarwal C, Singh RP and Agarwal R: Silibinin suppresses growth of human colorectal carcinoma SW480 cells in culture and xenograft through down-regulation of beta-catenin-dependent signaling. Neoplasia 12: 415-424, 2010.

130. He L, Lu N, Dai Q, Zhao Y, Zhao L, Wang H, Li Z, You Q and Guo Q: Wogonin induced G1 cell cycle arrest by regulating Wnt//-catenin signaling pathway and inactivating CDK8 in human colorectal cancer carcinoma cells. Toxicology 312: 36-47, 2013.

131. Predes D, Oliveira LFS, Ferreira LSS, Maia LA, Delou JMA, Faletti A, Oliveira I, Amado NG, Reis AH, Fraga CAM, et al: The chalcone lonchocarpin inhibits Wnt/ $\beta$-catenin signaling and suppresses colorectal cancer proliferation. Cancers (Basel) 11: 1968, 2019.

132. Bastos LG, de Marcondes PG, de-Freitas-Junior JC, Leve F, Mencalha AL, de Souza WF, de Araujo WM, Tanaka MN Abdelhay ES and Morgado-Díaz JA: Progeny from irradiated colorectal cancer cells acquire an EMT-like phenotype and activate Wnt/ $\beta$-catenin pathway. J Cell Biochem 115: 2175-2187, 2014

133. Jang E, Inn KS, Jang YP, Lee KT and Lee JH: Phytotherapeutic activities of sanguisorba officinalis and its chemical constituents: A review. Am J Chin Med 46: 299-318, 2018.

134. Liu MP, Li W, Dai C, Lam CWK, Li Z, Chen JF, Chen ZG, Zhang W and Yao MC: Aqueous extract of Sanguisorba officinalis blocks the Wnt/ $\beta$-catenin signaling pathway in colorectal cancer cells. Rsc Adv 8: 10197-10206, 2018.

135. Kang YJ, Park HJ, Chung HJ, Min HY, Park EJ, Lee MA, Shin $Y$ and Lee SK: Wnt/ $\beta$-catenin signaling mediates the antitumor activity of magnolol in colorectal cancer cells. Mol Pharmacol 82: 168-177, 2012.

136. Wei LH, Lin JM, Chu JF, Chen HW, Li QY and Peng J: Scutellaria barbata D. Don inhibits colorectal cancer growth via suppression of $\mathrm{Wnt} / \beta$-catenin signaling pathway. Chin J Integr Med 23: 858-863, 2017.

137. Zhao Q, Bi Y, Zhong J, Ren Z, Liu Y, Jia J, Yu M, Tan Y, Zhang $\mathrm{Q}$ and $\mathrm{Yu} \mathrm{X}$ : Pristimerin suppresses colorectal cancer through inhibiting inflammatory responses and $\mathrm{Wnt} / \beta$-catenin signaling. Toxicol Appl Pharmacol 386: 1148131, 2020.

138. Song L, Xu XB and Li ZY: A serine protease extracted from Trichosanthes kirilowii inhibits epithelial-mesenchymal transition via antagonizing PKM2-mediated STAT3/Snail1 pathway in human colorectal adenocarcinoma cells. J Funct Food 40 639-647, 2018.

139. Yang P, Liu W, Fu R, Ding GB, Amin S and Li Z: Cucurbitacin E chemosensitizes colorectal cancer cells via mitigating TFAP4/Wnt/ $\beta$-catenin signaling. J Agric Food Chem 2020 (Epub ahead of print).

140. Boudreau MD, Mellick PW, Olson GR, Felton RP, Thorn BT and Beland FA: Clear evidence of carcinogenic activity by a whole-leaf extract of Aloe barbadensis miller (Aloe vera) in F344/N rats. Toxicol Sci 131: 26-39, 2013

141. Peng C, Zhang W, Shen X, Yuan Y, Li Y, Zhang W and Yao M: Post-transcriptional regulation activity through alternative splicing involved in the effects of Aloe vera on the Wnt/ $\beta$-catenin and Notch pathways in colorectal cancer cells. J Pharmacol Sci 143: 148-155, 2020

142. Boudreau MD, Beland FA, Nichols JA and Pogribna M: Toxicology and carcinogenesis studies of a nondecolorized [corrected] whole leaf extract of Aloe barbadensis Miller (Aloe vera) in $\mathrm{F} 344 / \mathrm{N}$ rats and $\mathrm{B} 6 \mathrm{C} 3 \mathrm{~F} 1$ mice (drinking water study). Natl Toxicol Program Tech Rep Ser 577: 1-266, 2013.

143. Yokohira M, Matsuda Y, Suzuki S, Hosokawa K, Yamakawa K, Hashimoto N, Saoo K, Nabae K, Doi Y, Kuno T and Imaida K: Equivocal colonic carcinogenicity of Aloe arborescens miller var. natalensis berger at high-dose level in a wistar hannover rat 2-y study. J Food Sci 74: T24-T30, 2009

144. Peng C, Zhang W, Dai C, Li W, Shen X, Yuan Y, Yan L, Zhang W and Yao M: Study of the aqueous extract of Aloe vera and its two active components on the $\mathrm{Wnt} / \beta$-catenin and Notch signaling pathways in colorectal cancer cells. J Ethnopharmacol 243: $112092,2019$.
145. Dai C, Liu MP, Zhang WJ, Lam CWK, Guo JR, Li W, Wu J, Chen JF, Chen ZG, Zhang W and Yao MC: A material-basis study of Aloe vera on the wnt/beta-catenin signaling pathway using a knockin/knockout method with high-speed countercurrent chromatography. RSC Adv 7: 38819-38829, 2017.

146. Vinson KE, George DC, Fender AW, Bertrand FE and Sigounas G: The Notch pathway in colorectal cancer. Int J Cancer 138: 1835-1842, 2016.

147. Zhou ZP, Wang LP, Hong ZS, Qiu CZ, Wang MZ, Chen ZX, Tang LF, Yu WS and Wang CX: Silencing GOLPH3 gene expression reverses resistance to cisplatin in HT29 colon cancer cells via multiple signaling pathways. Int J Oncol 53: 1183-1192, 2018.

148. Wu X, Luo F, Li J, Zhong X and Liu K: Tankyrase 1 inhibitior XAV939 increases chemosensitivity in colon cancer cell lines via inhibition of the Wnt signaling pathway. Int J Oncol 48: 1333-1340, 2016

149. Longley DB, Harkin DP and Johnston PG: 5-fluorouracil: Mechanisms of action and clinical strategies. Nat Rev Cancer 3: 330-338, 2003

150. Yu ZW, Zhao P, Liu M, Dong XS, Tao J, Yao XQ, Yin XH, Li Y and Fu SB: Reversal of 5-flouroucial resistance by adenovirus-mediated transfer of wild-type p53 gene in multidrug-resistant human colon carcinoma LoVo/5-FU cells. World J Gastroenterol 10: 1979-1983, 2004.

151. Zhang Z,Zhang Y, Qin X, Wang Y and Fu J: FGF9 promotes cisplatin resistance in colorectal cancer via regulation of $W n t / \beta$-catenin signaling pathway. Exp Ther Med 19: 1711-1718, 2020.

152. Leushacke M, Sporle R, Bernemann C, Brouwer-Lehmitz A, Fritzmann J, Theis M, Buchholz F, Herrmann BG and Morkel M: An RNA interference phenotypic screen identifies a role for FGF signals in colon cancer progression. PLoS One 6: e23381, 2011.

153. Qiu CZ, Wang MZ, Yu WS, Guo YT, Wang CX and Yang XF: Correlation of GOLPH3 gene with Wnt signaling pathway in human colon cancer cells. J Cancer 7: 928-934, 2016.

154. Gonçalves JM, Silva CAB, Rivero ERC and Cordeiro MMR: Inhibition of cancer stem cells promoted by Pimozide. Clin Exp Pharmacol Physiol 46: 116-125, 2019.

155. Rubinstein MR, Wang X, Liu W, Hao Y, Cai G and Han YW: Fusobacterium nucleatum promotes colorectal carcinogenesis by modulating E-cadherin/ $\beta$-catenin signaling via its FadA adhesin. Cell Host Microbe 14: 195-206, 2013.

156. Rubinstein MR, Baik JE, Lagana SM,Han RP, Raab WJ, Sahoo D, Dalerba P, Wang TC and Han YW: Fusobacterium nucleatum promotes colorectal cancer by inducing Wnt/ $\beta$-catenin modulator Annexin A1. EMBO Rep 20: e47638, 2019

157. Li X, Huang J, Yu T, Fang X, Lou L, Xin S, Ji L, Jiang F and Lou Y: Fusobacterium nucleatum promotes the progression of colorectal cancer through Cdk5-Activated Wnt/ $\beta$-Catenin Signaling. Front Microbiol 11: 545251, 2021.

158. Ghanavati R, Akbari A, Mohammadi F, Asadollahi P, Javadi A, Talebi $\mathrm{M}$ and Rohani M: Lactobacillus species inhibitory effect on colorectal cancer progression through modulating the Wnt/ $\beta$-catenin signaling pathway. Mol Cell Biochem 470: 1-13, 2020 .

159. Basso K, Saito M, Sumazin P, Margolin AA, Wang K, Lim WK, Kitagawa Y, Schneider C, Alvarez MJ, Califano A and Dalla-Favera R: Integrated biochemical and computational approach identifies BCL6 direct target genes controlling multiple pathways in normal germinal center B cells. Blood 115: 975-984, 2010.

160. Cha N, Liu W, Yang N, Xie S, Gao Y, Chen X, Wang X and Ren J: Oncogenicity of LHX4 in colorectal cancer through Wnt/3-catenin/TCF4 cascade. Tumour Biol 35: 10319-10324, 2014.

161. Cheng F, Mohanmed MM, Li Z, Zhu L, Zhang Q, Huang Q and Shen W: Capn 4 promotes colorectal cancer cell proliferation by increasing MAPK 7 through activation of the Wnt/ $\beta$-Catenin pathway. Exp Cell Res 363: 235-242, 2018.

162. Shen J, Yu Z and Li N: The E3 ubiquitin ligase RNF146 promotes colorectal cancer by activating the Wnt/ $\beta$-catenin pathway via ubiquitination of Axin1. Biochem Biophys Res Commun 503: 991-997, 2018.

163. Zhang QW, Zhang XT, Tang CT, Lin XL, Ge ZZ and Li XB: EGFL6 promotes cell proliferation in colorectal cancer via regulation of the WNT/ $\beta$-catenin pathway. Mol Carcinog 58: 967-979, 2019.

164. Zhou C, Li Y, Wang G, Niu W, Zhang J, Wang G, Zhao Q and Fan L: Enhanced SLP-2 promotes invasion and metastasis by regulating Wnt/ $\beta$-catenin signal pathway in colorectal cancer and predicts poor prognosis. Pathol Res Pract 215: 57-67, 2019. 
165. Mir R, Pradhan SJ, Patil P, Mulherkar R and Galande S: Wnt $/ \beta$-catenin signaling regulated SATB1 promotes colorectal cancer tumorigenesis and progression. Oncogene 35: 1679-1691, 2016.

166. Lu W, Fu Z, Wang H, Feng J, Wei J and Guo J: Peroxiredoxin 2 knockdown by RNA interference inhibits the growth of colorectal cancer cells by downregulating Wnt/ $\beta$-catenin signaling. Cancer Lett 343: 190-199, 2014.

167. Koo BK,Spit M, Jordens I,Low TY, Stange DE, van deWetering M, van Es JH, Mohammed S, Heck AJ, Maurice MM and Clevers H Tumour suppressor RNF43 is a stem-cell E3 ligase that induces endocytosis of Wnt receptors. Nature 488: 665-669, 2012.

168. Jiang X, Charlat O, Zamponi R, Yang Y and Cong F: Dishevelled promotes Wnt receptor degradation through recruitment of ZNRF3/RNF43 E3 ubiquitin ligases. Mol Cell 58: 522-533, 2015

169. Guo Q, Wu M, Lian P, Liao M, Xiao Z, Wang X and Shen S: Synergistic effect of indomethacin and NGX6 on proliferation and invasion by human colorectal cancer cells through modulation of the Wnt/beta-catenin signaling pathway. Mol Cell Biochem 330: 71-81, 2009.

170. Lee JH, Bae JA, Lee JH, Seo YW, Kho DH, Sun EG, Lee SE, Cho SH, Joo YE, Ahn KY, et al: Glycoprotein 90K, downregulated in advanced colorectal cancer tissues, interacts with CD9/CD82 and suppresses the Wnt/beta-catenin signal via ISGylation of beta-catenin. Gut 59: 907-917, 2010.

171. Tong X, Zhuang Z, Wang X, Yang X, Bai L, Su L, Wei P and Su X: ACBP suppresses the proliferation, migration, and invasion of colorectal cancer via targeting Wnt/beta-catenin signaling pathway. Biomed Pharmacother 137: 111209, 2021.

172. Meng WJ, Yan H, Li Y and Zhou ZG: SATB1 and colorectal cancer in Wnt/ $\beta$-catenin signaling: Is there a functional link? Med Hypotheses 76: 277-279, 2011.
173. Gou H, Liang JQ, Zhang L, Chen H, Zhang Y, Li R, Wang X, Ji J, Tong JH, To KF, et al: TTPAL promotes colorectal tumorigenesis by stabilizing TRIP6 to activate Wnt/ $\beta$-catenin signaling. Cancer Res 79: 3332-3346, 2019.

174. Jiang S, Song C, Gu X, Wang M, Miao D, Lv J and Liu Y: Ubiquitin-specific peptidase 22 contributes to colorectal cancer stemness and chemoresistance via Wnt//-Catenin pathway. Cell Physiol Biochem 46: 1412-1422, 2018.

175. Jiang S, Miao D, Wang M, Lv J, Wang Y and Tong J: MiR-30-5p suppresses cell chemoresistance and stemness in colorectal cancer through USP22/Wnt/ $\beta$-catenin signaling axis. J Cell Mol Med 23: 630-640, 2019.

176. Huang T, Zhang Q, Ren W, Yan B, Yi L, Tang T, Lin H and Zhang Y: USP44 suppresses proliferation and enhances apoptosis in colorectal cancer cells by inactivating the Wnt/ $\beta$-catenin pathway via Axin1 deubiquitination. Cell Biol Int 44: 1651-1659, 2020.

177. Ohsugi T, Yamaguchi K, Zhu C, Ikenoue T, Takane K, Shinozaki M, Tsurita G, Yano H and Furukawa Y: Anti-apoptotic effect by the suppression of IRF1 as a downstream of Wnt/ $\beta$-catenin signaling in colorectal cancer cells. Oncogene 38 : 6051-6064, 2019.

178. Ohsugi T, Yamaguchi K, Zhu C, Ikenoue T and Furukawa Y: Decreased expression of interferon-induced protein 2 (IFIT2) by Wnt/beta-catenin signaling confers anti-apoptotic properties to colorectal cancer cells. Oncotarget 8: 100176-100186, 2017. International (CC BY-NC-ND 4.0) License. 